\title{
Patterns and mechanisms of early Pliocene warmth
}

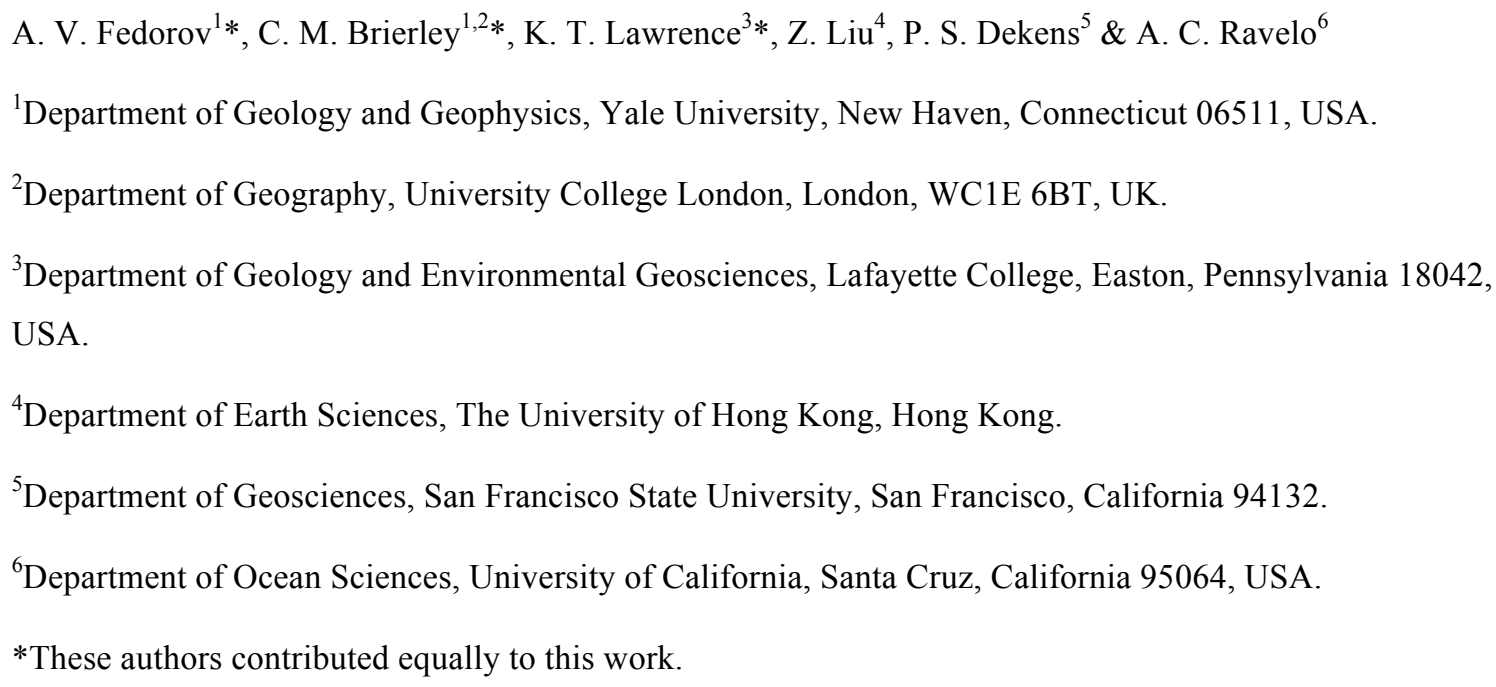

About five to four million years ago, in the early Pliocene epoch, Earth had a warm, temperate climate. The gradual cooling that followed led to the establishment of modern temperature patterns, possibly in response to a decrease in atmospheric $\mathrm{CO}_{2}$ concentration, on the order of 100 parts per million, towards preindustrial values. Here, we synthesize the available geochemical proxy records of sea surface temperature and show that, compared with that of today, the early Pliocene climate had substantially lower meridional and zonal temperature gradients, but quite similar maximum ocean temperatures Using an Earth system model, we show that none of the mechanisms currently proposed to explain Pliocene warmth can simultaneously reproduce all three crucial features. We suggest that a combination of several dynamical feedbacks, such as those related to ocean mixing and cloud albedo which are underestimated in the models at present, , was responsible for these climate conditions. Earth's climate evolution over the last five million years (Myr), since the early Pliocene epoch, has been meticulously studied by scientists (see, for example, refs 1-3). For years, the focus of attention was on the origin ${ }^{4-6}$ of glacial cycles, that is, the coming and going of continental ice sheets evident in the $\delta^{18} \mathrm{O}$ record reflecting global ice volume and deep-ocean temperature (Fig. 1a). However, a wealth of new data now show that the gradual onset (around $3 \mathrm{Myr}$ ago) and further amplification of Northern Hemisphere glaciation (Fig. 1b) 
was only one facet of this climate change and was a consequence of the global cooling rather than its initial cause $\mathrm{c}^{7,8}$.

The early Pliocene itself, the warm interval that preceded the glaciation, has attracted a lot of attention as a possible analogue for future climate conditions. Despite relatively small differences in climate control factors, including $\mathrm{CO}_{2}$ concentrations (Fig. 1c), between the early Pliocene and the present, the former was markedly different ${ }^{9}$. Palaeorecords indicate vast changes in climate patterns since 5-4 Myr ago, including a contraction of the tropical belt and oceanic warm pool ${ }^{10}$, emergence of strong temperature gradients along the Equator $^{11}$, cooling of coastal upwelling zones in the subtropics ${ }^{12}$, the shoaling of the ocean thermocline ${ }^{11,13}$ and cooling of the high-latitude and deep ocean ${ }^{14,15}$. Together these observations imply a large structural change in climate, with major global and regional implications.

By a structural change, we mean a transition from a climate with almost no zonal sea surface temperature (SST) gradients $\left(\sim 1^{\circ} \mathrm{C}\right.$ or less) and a weak meridional SST gradient to a modern climate with much more pronounced spatial temperature contrasts. This structural climate change was paralleled by relatively small changes in atmospheric $\mathrm{CO}_{2}$ concentration (Fig. 1c), on the order of $\sim 100$ p.p.m. Thus, a key step towards understanding early Pliocene climate, and possibly other warm climates throughout Earth history, is to explain what could cause such changes.

The objectives of this article are twofold. First, we review recent geochemically derived palaeorecords emphasizing the three criteria that any hypothesis must satisfy to account for the climate of the early Pliocene (reduced meridional temperature gradient, weak zonal gradients and SST stability). Then we evaluate various explanations for early Pliocene climate with respect to these criteria, using a single modelling framework.

\section{Observations}

Substantial effort has been put into deriving palaeoclimate records for the Pliocene because it is recognized as the most recent example of prolonged global warmth in the geological past $^{2,16}$. As part of the PRISM project, this effort produced a series of global temperature reconstructions $^{17,18}$ for a 'time slab' of the mid Pliocene (3-3.3 Myr ago). These data sets and 
associated modelling studies enable a coordinated comparison between the Pliocene and the present, and dramatically increased our understanding of Pliocene climate.

In the present study, we compile available SST proxy records, most of them continuous, to describe the long-term climate trends from the warm early Pliocene to the present (Fig. 2 and Methods). As several of these records indicate, the period from 4.4 to 4 Myr ago was probably the warmest interval within this timeframe - the Pliocene climatic optimum (Fig. 2b, c). The subsequent cooling became evident roughly at the same time in both hemispheres (Fig. 2c, d) and involved regions ranging from low-latitude upwelling zones to mid and high latitudes. The expansion of the Northern Hemisphere ice sheets around 2.7 Myr ago, evidenced by an increase in the magnetic susceptibility of sediments affected by ice-rafted debris (Fig. 1b), introduced a strong interhemispheric asymmetry in the climate evolution over land ${ }^{19}$ but to a lesser degree over the ocean (as shown by the similarity of trends in Fig. 3c, d).

Within the global cooling pattern, local trends featured significant spatial and temporal variations not necessarily tracking the growth of continental ice sheets inferred from $\delta^{18} \mathrm{O}$ data (Fig. 1a). Regionally, temperature changes were as high as $11^{\circ} \mathrm{C}$ over the ocean $^{20}$ (Fig. 3c) and $19{ }^{\circ} \mathrm{C}$ over the land ${ }^{19}$. Below, we focus on the critical features that characterize the evolution of climate structure since the early Pliocene. As is traditionally done by the palaeoclimatology community, here we compare the mean trends incorporating both glacial and interglacial intervals of the time series, even though some of our statements contrast the late Quaternary interglacials and Pliocene interglacials. A comparison between the mean and 'interglacial' trends supports our main conclusions (Methods and Supplementary Figs 1-3).

\section{Warm pool temperatures and $\mathrm{CO}_{2}$}

The first notable aspect of the Pliocene-Pleistocene climate evolution is the stability of warmest SSTs in the tropical warm pool over the past 5 Myr. In all three tropical oceans, these temperatures stayed fairly constant and the long-term average remained $\sim 29^{\circ} \mathrm{C}$ (Figs $2 \mathrm{a}$ and $3 \mathrm{a}$ ), similar to the present. This is especially surprising given temperature changes elsewhere. It has been suggested that $\mathrm{Mg} / \mathrm{Ca}$-based measurements, providing many warm pool records, should be corrected for secular changes in seawater composition ${ }^{21}$. However, 
general agreement between $\mathrm{Mg} / \mathrm{Ca}$ and alkenone data in locations where both proxies are available (ref. 12 and Methods) indicates that this correction should be small, comparable to calibration errors ${ }^{12}$.

Although a number of thermostat mechanisms capable of maintaining the stability of warm pool SST in high- $\mathrm{CO}_{2}$ climates have been proposed ${ }^{22}$, we find them unnecessary to explain the Pliocene climate. A pervasive increase in atmospheric $\mathrm{CO}_{2}$ is the driver for present anthropogenic climate change, and is expected to cause even larger changes in the future ${ }^{16}$. Similarly, $\mathrm{CO}_{2}$ remains a suspected cause for early Pliocene warmth, and several biogeochemical methods have been devised to estimate its concentration (Fig. 1c). Despite large uncertainties, together these proxy data suggest that Pliocene $\mathrm{CO}_{2}$ concentrations were only $\sim 100$ p.p.m. higher than preindustrial values ( $\sim 280$ p.p.m). Climate models produce a $\sim 1{ }^{\circ} \mathrm{C}$ temperature rise in the warm pool when the $\mathrm{CO}_{2}$ concentration increases by 100 p.p.m. ${ }^{16}$, and a change by $\sim 2{ }^{\circ} \mathrm{C}$ in doubling-of- $\mathrm{CO}_{2}$ experiments ${ }^{23}$. Thus, within data uncertainty (Methods), the stability of the warm pool temperatures is not inconsistent with the relatively small $\mathrm{CO}_{2}$ change.

\section{Increasing meridional temperature gradients}

High-latitude warmth and a reduced Equator-to-pole temperature gradient are other dominant features of early Pliocene climate ${ }^{2,24}$. Marine data, available between latitudes $43^{\circ} \mathrm{S}$ and $58^{\circ} \mathrm{N}$ (Fig. 2e), suggest subsequent ocean cooling of $4-7^{\circ} \mathrm{C}$ in the mid and high latitudes of the Atlantic and Pacific (Figs 2d and 3d). The temperature of Atlantic deep waters (ODP site 607; 3,400-m depth) basically follows SST evolution in the North Atlantic, implying a similar cooling over the ocean convection regions at higher latitudes $\left(\sim 70^{\circ} \mathrm{N}\right)$. In terrestrial regions of the Arctic, temperature fell by nearly $19^{\circ} \mathrm{C}$ (ref. 19).

The meridional SST gradient as measured from the Equator to the subtropics was also significantly smaller in the early Pliocene than at present $^{10}$ (Fig. $4 \mathrm{a}-\mathrm{c}$ ), and the meridional temperature distribution within the Tropics was more uniform ${ }^{10}$. Consequently, despite little difference in the warmest SSTs (Figs 2a and 3a), the meridional extent of the warm pool was much broader in the early Pliocene. The subsequent cooling led to a gradual contraction of the warm pool towards the Equator, as evidenced by the increase in meridional temperature gradient. This contraction is also apparent from temperature records at the edge of the warm 
pool in the South China Sea ${ }^{25,26}$ (Supplementary Fig. 9). Whereas data from inside the warm pool show fairly constant temperatures, these particular records show a clear cooling trend.

The reduced meridional SST gradient seems to be important for understanding the high global mean temperature and other characteristics of the early Pliocene ${ }^{8,10}$. For instance, from the atmospheric perspective, as the temperature contrast from the Equator to the subtropics increased, the surface high-pressure zones in low latitudes (subtropical highs) strengthened, whereas the atmospheric meridional circulation (the Hadley cells) intensified and contracted slightly towards the Equator. The strengthening of atmospheric circulation led to a stronger subsidence, resulting in aridification of parts of Africa, Australia and North America $^{8,27}$.

From the tropical oceanic perspective, as the meridional SST gradient increased, so did upper ocean stratification, because oceanic vertical thermal structure is directly related to the surface temperature distribution ${ }^{28,29}$. This increase in stratification should have contributed to the basin-wide shoaling of the tropical thermocline $e^{9,30,31}$, which has been under way since 5 Myr ago ${ }^{13,31}$.

\section{Strengthening of cold upwelling}

As the meridional SST gradient increased and the tropical thermocline shoaled, cold waters became present at low latitudes, with dramatic consequences for the tropics. Initially the cold waters appeared in the coastal subtropical upwelling sites in the Atlantic and Pacific oceans, in both hemispheres (Fig. 2c and 3c). The strengthening of anticyclonic winds within the subtropical highs may have contributed to the stronger upwelling ${ }^{8,10}$.

The shoaling of the thermocline culminated in the appearance of colder water along the Equator (Figs $2 \mathrm{~b}$ and $3 \mathrm{~b}$ ) and the formation of a salient feature of the present-day SST pattern, namely the equatorial 'cold tongues' on the eastern sides of the Pacific and Atlantic basins. The corresponding development of the zonal temperature gradients along the Equator (Fig. 4d-f) and the ensuing Bjerknes feedback (a stronger SST gradient leads to stronger winds and, thence, a stronger gradient) led to the intensification of the zonal atmospheric circulation-the Walker cell ${ }^{3,10}$.

In the present climate, an intermittent weakening of both the winds and the east-west equatorial temperature gradient occurs during El Niño, but the mean climate is still 
characterized by pronounced cold tongues in the Pacific and the Atlantic. These tongues are maintained by a persistent supply of colder water from the extratropics by shallow overturning cells ${ }^{32}$. The cold tongues and subtropical coastal upwelling zones are the main low-latitude regions where the ocean gains heat to balance that lost in high latitudes ${ }^{27,28}$. Apparently, during the early Pliocene the cold water was mainly absent in the eastern equatorial Pacific, and the zonal SST gradient along the Equator was small (Fig. 4d-f). This state is sometimes referred to as 'permanent El Niño-like"11 (although it implies nothing about interannual variability). A similar situation occurred in the Atlantic (Fig. 2a, b).

The zonal SST gradient in the two oceans reached its modern values between 2 and 1 Myr ago (Fig. 4). This was a gradual process rather than a swift transition. The magnitude of cooling of the eastern equatorial Pacific ( $4-5^{\circ} \mathrm{C}$ over $\left.4 \mathrm{Myr}\right)$ approximately matches that in mid latitudes (Fig. 3b, d).

A zonal SST gradient also developed in the Indian Ocean, where seasonal coastal upwelling became prominent in the Arabian Sea (Figs $2 b$ and 3b). The cooling in this region since the early Pliocene may have contributed to a gradual strengthening of the Asian monsoon through coupling between the winds and SSTs (stronger winds lead to a greater SST contrast and, in turn, yet stronger winds). In an atmospheric general circulation model (GCM), transitioning from a uniformly warm Indian Ocean to a cooler Arabian Sea leads to the strengthening of the monsoon and the aridification of East Africa ${ }^{8}$.

\section{Mechanisms to explain Pliocene climate}

Simulations with atmospheric GCMs forced with different Pliocene SST reconstructions suggest that the global mean temperature was $2-3{ }^{\circ} \mathrm{C}$ higher ${ }^{33}$ in the mid Pliocene $(\sim 3 \mathrm{Myr}$ ago) and roughly $4{ }^{\circ} \mathrm{C}$ higher ${ }^{8}$ in the early Pliocene ( 4 Myr ago) than the preindustrial temperature. Many studies have focused on the related problem of how the Northern Hemisphere stayed almost free of continental ice before the onset of the ice ages ${ }^{2,5,34,35}$. Several hypotheses were proposed, ranging from high $\mathrm{CO}_{2}$ to enhanced ocean poleward heat transport $^{2,24}$ caused by changes in ocean gateways ${ }^{5,35}$ and to changes in atmospheric processes and feedbacks.

However, the Pliocene problem ${ }^{9}$ goes much farther than the issues of mean global temperatures or continental ice sheets. Accordingly, here we conduct experiments with a 
state-of-the-art coupled model (Methods) to explore whether these prevailing hypotheses are consistent with the three observational constraints on changes in tropical climate between the present and the early Pliocene, that is, the reduction of meridional temperature gradient by 4 $6{ }^{\circ} \mathrm{C}$ between the Equator and, respectively, $30^{\circ} \mathrm{N}$ and $30^{\circ} \mathrm{S}$; a similar $4-6^{\circ} \mathrm{C}$ reduction of zonal SST gradient in the equatorial Pacific; and little SST increase $\left(0-1^{\circ} \mathrm{C}\right)$ in the warm pool.

\section{Higher atmospheric $\mathrm{CO}_{2}$}

In the first experiment, we increase $\mathrm{CO}_{2}$ by 100 p.p.m. starting from the preindustrial climate. As expected, the climate response to this increase is amplified in high latitudes, leading to a reduction of the Equator-to-pole temperature gradient. Nevertheless, this reduction between the Equator and mid latitudes reaches only $0.5^{\circ} \mathrm{C}$ (Fig. 5a). The eastern equatorial Pacific warms by the same amount, but so does the warm pool. As a result, the zonal gradients hardly change, whereas the tropical thermocline deepens but very little (Fig. 5f). Typically, in other models ${ }^{36}$, even for $\mathrm{CO}_{2}$ doubling, changes in this gradient do not exceed $\pm 0.5^{\circ} \mathrm{C}$, suggesting that $\mathrm{CO}_{2}$ alone cannot explain the early Pliocene SST patterns.

A comprehensive simulation ${ }^{37}$ of the mid Pliocene forced by $\mathrm{CO}_{2}$ concentrations of 400 p.p.m. and PRISM3 land surface boundary conditions shows an increase in global mean temperature of around $3{ }^{\circ} \mathrm{C}$, of which half comes from the $\mathrm{CO}_{2}$ increase and the rest from lower orography and reduced land albedo. The model simulates a warming by $3-4{ }^{\circ} \mathrm{C}$ in some regions of the high-latitude Atlantic, partly attributed to the effect of a smaller Greenland ice sheet ${ }^{15,33,34}$; however, SST gradients at low latitudes change little while temperature in the warm pool rises by $2-3{ }^{\circ} \mathrm{C}$. This confirms that with the relatively minor increase ( $\sim 100$ p.p.m.), $\mathrm{CO}_{2}$ alone could not induce the observed structural climate change, even with high Earth-system climate sensitivity ${ }^{37}$.

\section{Ocean gateways}

Enhanced ocean poleward heat transport during the Pliocene has been proposed as another factor that contributes to keeping high latitudes warm, especially in the northern Atlantic ${ }^{2,24}$. However, climate models calculate changes in ocean heat transport interactively and so require particular forcing mechanisms, such as an open Central American seaway ${ }^{31,38}$ (CAS). 
Originally, the CAS closure was discussed in the context of the onset of glaciation around 2.7 $\mathrm{Myr}_{\text {ago }}{ }^{38}$, but the closure is now estimated to have occurred between 4.7 and 4.2 Myr ago, as inferred from the divergence of planktonic $\delta^{18} \mathrm{O}$ between the Caribbean Sea and the Pacific ${ }^{5,31,39}$. Recently, it has been suggested that the seaway closure, and the resulting intensification of deep-ocean circulation due to increased salinity in the Atlantic, could have led to a shoaling of the thermocline in the Pacific, facilitating the subsequent cooling ${ }^{31}$.

Opening the CAS in our model to a depth of $150 \mathrm{~m}$ (ref. 5) causes a reduction in the strength of the Atlantic meridional overturning circulation, a cooling of the Northern Hemisphere and a warming of the Southern Hemisphere (Fig. 5c, h and Supplementary Fig. 11). However, impacts on the equatorial SSTs are minor. The equatorial thermocline deepens a little in the central Pacific but shoals in the very east. Opening the CAS to the largest possible depth, 1,100 m, barely changes the zonal SST gradient along the Equator, but amplifies the interhemispheric seesaw pattern with a strong cooling in the northern high latitudes (Supplementary Fig. 11), contradicting the observations. Similar behaviour is seen in other models (ref. 40; Supplementary Fig. 12).

Another tectonic factor potentially important for Pliocene climate is the northward drift of New Guinea, which may have altered the source of waters entering the Indonesian throughflow and feeding the Equatorial undercurrent and upwelling ${ }^{41}$. However, in agreement with previous modelling studies ${ }^{42}$, our results show impacts barely above statistical significance (Fig. 5b, g), and do not explain the Pliocene climate state.

\section{Effects of ocean mixing and cloud albedo}

Recently, dynamical feedbacks not included or possibly underestimated in climate models have also been suggested to explain early Pliocene warmth ${ }^{43,44}$. In particular, it has been argued that tropical cyclones during that time were more widespread, generating strong ocean vertical mixing in the subtropical bands. Such enhanced mixing would reduce oceanic heat transport from the equatorial region to the subtropics, deepening the tropical thermocline and warming the cold tongue. Presumably, the contraction of the warm pool and associated strengthening of vertical wind shear decreased tropical cyclone activity, contributing to the cooling trends ${ }^{44}$. 
Our experiments show that a plausible increase in the subtropical mixing (Supplementary Fig. 13b) causes a reduction of the zonal SST gradient in the Pacific by $\sim 2{ }^{\circ} \mathrm{C}$, which is promising (Fig. $5 \mathrm{~d}, \mathrm{i}$ ). This is the only experiment that causes a broad deepening of the thermocline along the Equator (Fig. 5i). However, the impacts also include an increase by almost $1^{\circ} \mathrm{C}$ in the meridional SST gradient (associated with ocean cooling in hurricane wakes), rather than the required reduction.

It has also been suggested that extratropical low stratus clouds were less reflective in the Pliocene ${ }^{43}$, possibly as a result of a different aerosol composition or a stronger cloud response to surface warming than coupled models typically predict. Our sensitivity experiment with a moderately reduced low-cloud albedo (Supplementary Fig. 13a) shows a reduction by $1-2{ }^{\circ} \mathrm{C}$ in the meridional SST gradient, a weak reduction in the zonal gradient, and a modest deepening of the tropical thermocline (Fig. 5e, j). However, somewhat like the $\mathrm{CO}_{2}$ experiment, this simulation increased warm pool SSTs while producing little change in the thermocline depth.

\section{Quantifying structural climate change}

We can assess how well these experiments capture a key characteristic of the Pliocene climate, that is, a more uniform SST field at low latitudes. A quantitative measure that reflects the structural aspects of climate change is the change in the spatial variance of timeaveraged temperatures evaluated for particular regions of the ocean (Supplementary Table 4). Weakened zonal and meridional temperature gradients imply less spatial diversity in temperature, and so the early Pliocene should have a smaller variance at low latitudes as compared to the present. None of the aforementioned simulations reduces the tropical variance computed within the band between $30^{\circ} \mathrm{N}$ and $30^{\circ} \mathrm{S}$ by more than $5 \%$, whereas some actually increase it. When computed for the equatorial band $\left(10^{\circ} \mathrm{N}\right.$ to $\left.10^{\circ} \mathrm{S}\right)$, the variance is $40 \%$ lower in the ocean-mixing experiment but less than $15 \%$ lower in the others.

\section{Discussion and outlook}

Palaeorecords allow us to identify critical features of the early Pliocene climate: it was a warm climate characterized by a minimal increase in warm pool SST but substantially weaker meridional and zonal SST gradients, and, hence, weaker atmospheric circulation $^{3,8,10,44}$, and a deeper tropical thermocline. These differences between the early 
Pliocene and modern climates amount to structural climate change, regardless of whether we consider trends in mean temperatures or interglacial temperatures (the latter are less affected by continental ice sheets than are the former).

Overall, we are just beginning to understand the driving forces behind climate evolution since the early Pliocene. The climatic changes occurred in concert with a relatively small reduction-less than $\sim 100$ p.p.m.-in atmospheric $\mathrm{CO}_{2}$ (Fig. 1c). Either this reduction pushed the system over a threshold, leading to the structural climate change, or the climate system was cooled by other mechanisms and $\mathrm{CO}_{2}$ provided a positive feedback for the cooling.

None of the currently proposed mechanisms can reproduce all of the key Pliocene climate features by itself. Some mechanisms address one aspect of the structural change, but often at the detriment of the other features; a major problem is to simulate reduced temperature gradients without raising warm pool SSTs. Increases in greenhouse gases alone are not sufficient, whereas shifts in oceanic gateways have much smaller effects than sometimes suggested. The most promising dynamical mechanisms invoke lower extratropical cloud albedo or enhanced ocean mixing. For these mechanisms to explain the stark differences between the Pliocene and today's climates, the corresponding model has to be modified.

Imposing the two dynamical mechanisms in a climate model while increasing $\mathrm{CO}_{2}$ (Fig. 6b) produces a warming by $\sim 3{ }^{\circ} \mathrm{C}$ in the eastern equatorial Pacific and a reduction by $2-4{ }^{\circ} \mathrm{C}$ in the meridional temperature gradient, leading to an increase of only $1{ }^{\circ} \mathrm{C}$ in the temperature of the warm pool. The spatial variance of SSTs decreases by $60 \%$ in the equatorial region (Supplementary Table 4), in a stark contrast with the $\mathrm{CO}_{2}$-only experiment (Fig. 6a). Thus, a combination of several factors may be necessary to explain Pliocene climate.

An important question is to what degree the evidence of climate evolution over the last 5 Myr shapes our assessment of future change. From the observations, it is clear that the climate system is capable of remarkable transformations even in response to small changes in external parameters $\left(\mathrm{CO}_{2}\right.$ concentrations, continental boundaries and orography are similar for the early Pliocene and present). Therefore, explaining the discrepancy between model 
simulations and the early Pliocene temperature patterns is essential for building confidence in our climate projections. Finally, it might be necessary to contemplate, in addition to global mean temperature increase, the possibility of structural climate change (relaxation of prevailing temperature gradients at low latitudes).

\section{METHODS SUMMARY}

All the geochemical records used to compute the trends presented in this article have been previously published. The ocean temperatures come from two geochemical proxies (alkenone unsaturation index $\left(U^{K^{\prime}}{ }_{37}\right)$ and $\mathrm{Mg} / \mathrm{Ca}$ ratios of planktonic foraminiferal shells) that are derived from material preserved in deep-sea sediment (Methods). These proxies are recorded by microorganisms living in the surface mixed layer of the ocean (except one record that comes from benthic foraminifers), where their chemical composition reflects the conditions of the surrounding water. The leading-order trends are computed as 400-kyr or 600-kyr running means for each temperature record, which filters out glacial-interglacial variability. The original data are included in Supplementary Information. The $\mathrm{CO}_{2}$ estimates were calculated using a variety of techniques (Supplementary Table 1) and are presented as originally published except the record based on $\delta^{13} \mathrm{C}$ (ref. 45), which was adjusted to subtract an offset (90 p.p.m.) between the original data and the Antarctic $\mathrm{CO}_{2}$ records.

The climate model used is the NCAR Community Earth System Model ${ }^{46}$. This incorporates an atmospheric model and a land surface model (CAM4 and CLM with a spectral truncation of $\mathrm{T} 31$ (a horizontal grid of $3.75^{\circ}$ by $3.75^{\circ}$ ) coupled to ocean and sea-ice components (POP2 and CICE, respectively) with a nominal $3^{\circ}$ resolution that increases to $1^{\circ}$ near the Equator. Each numerical experiment is designed to examine the effects of a single type of perturbation with respect to a preindustrial baseline simulation (a change in a particular ocean gateway or a change in cloud properties, for example). In the final experiment, titled 'Combined', we imposed three different perturbations together (enhanced ocean mixing in the subtropical bands, reduced albedo of low extratropical clouds and a 100p.p.m. $\mathrm{CO}_{2}$ increase). For each experiment, the simulation time was $500 \mathrm{yr}$, with the final 25 yr being used for analysis. Further details are provided in Methods.

Received 16 October 2012; accepted 11 February 2013; doi:10.1038/nature12003. 
$<\mathrm{jrn}>1$. Shackleton, N. J. et al. Oxygen isotope calibration of the onset of ice-rafting and history of glaciation in the North Atlantic region. Nature 307, 620-623 (1984). </jrn>

$<$ jrn $>2$. Crowley, T. Pliocene climates: the nature of the problem. Mar. Micropaleontol. 27, 3-12 (1996). $</$ jrn $>$

$<$ jrn>3. Ravelo, A. C., Andreasen, D. H., Lyle, M., Lyle, A. O. \& Wara, M. W. Regional climate shifts caused by gradual global cooling in the Pliocene epoch. Nature 429, 263-267 (2004). </jrn>

$<$ jrn $>4$. Jansen, E., Fronval, T., Rack, F. \& Channell, J. E. T. Pliocene-Pleistocene ice rafting history and cyclicity in the Nordic seas during the last 3.5 Myr. Paleoceanography 15, 709-721 (2000). $</$ jrn $>$

$<$ jrn $>5$. Haug, G., Tiedemann, R., Zahn, R. \& Ravelo, A. Role of Panama uplift on oceanic freshwater balance. Geology 29, 207-210 (2001). </jrn>

$<$ jrn $>6$. Ruddiman, W. Orbital insolation, ice volume, and greenhouse gases. Quat. Sci. Rev. 22, 1597-1629 (2003). </jrn>

$<$ jrn $>$ 7. Crowley, T. \& Hyde, W. Transient nature of late Pleistocene climate variability. Nature 456, 226-230 (2008). $</$ jrn $>$

$<$ unknown $>8$. Brierley, C. \& Fedorov, A. Relative importance of meridional and zonal sea surface temperature gradients for the onset of the ice ages and Pliocene-Pleistocene climate evolution. Paleoceanography 25, PA2214 (2010). </unknown> [AUTHOR: Journal article: doi: 10.1029/2009PA001809.]

$<$ jrn $>9$. Fedorov, A. et al. The Pliocene paradox (mechanisms for a permanent El Niño). Science 312, 1485-1489 (2006). </jrn>

$<$ jrn $>10$. Brierley, C. M. et al. Greatly expanded tropical warm pool and weakened Hadley circulation in the early Pliocene. Science 323, 1714-1718 (2009).</jrn>

$<$ jrn>11. Wara, M. W., Ravelo, A. C. \& Delaney, M. L. Permanent El Niño-like conditions during the Pliocene warm period. Science 309, 758-761 (2005). </jrn> 
$<$ jrn>12. Dekens, P., Ravelo, A., McCarthy, M. \& Edwards, C. A 5 million year comparison of $\mathrm{Mg} / \mathrm{Ca}$ and alkenone paleothermometers. Geochem. Geophys. Geosyst. 9, Q10001 (2008).</jrn>

$<$ jrn $>$ 13. Steph, S., Tiedemann, R., Groeneveld, J., Sturm, A. \& Nurnberg, D. Pliocene changes in tropical east Pacific upper ocean stratification: Response to tropical gateways? Proc. Ocean Drill. Program Sci. Results 202, 1-51 (2006). $<$ jrn>

<unknown>14. Lawrence, K., Herbert, T., Brown, C., Raymo, M. \& Haywood, A. High-amplitude variations in North Atlantic sea surface temperature during the early Pliocene warm period. Paleoceanography 24, PA2218 (2009).</unknown> [AUTHOR: Journal article: doi: 10.1029/2008PA001669.]

$<$ jrn $>$ 15. Sosdian, S. \& Rosenthal, Y. Deep-sea temperature and ice volume changes across the Pliocene-Pleistocene climate transitions. Science 325, 306-310 (2009). $<$ jrn $>$

$<\mathrm{edb}>$ 16. Solomon, S. et al. (eds) Climate Change 2007: The Physical Science Basis (Cambridge Univ. Press, 2007). $</$ edb $>$

$<$ other $>$ 17. Dowsett, H. J. et al. Middle Pliocene Paleoenvironmental Reconstruction: PRISM2. Open File Report 99-535 (US Geol. Surv., 1999).</other>

$<$ unknown $>18 . \quad$ Dowsett, H. J. et al. The PRISM3D paleoenvironmental reconstruction. Stratigraphy 7, 123-139 (2010).</unknown>

$<\mathrm{jrn}>19$. Ballantyne, A. et al. Significantly warmer arctic surface temperatures during the Pliocene indicated by multiple independent proxies. Geology 38, 603-606 (2010). $<$ jrn $>$

$<$ jrn $>20$. Marlow, J., Lange, C., Wefer, G. \& Rosell-Mele, A. Upwelling intensification as part of the Pliocene-Pleistocene climate transition. Science 290, 2288-2291 $(2000) \cdot</ \mathrm{jrn}>$

$<$ jrn $>21$. Medina-Elizalde, M., Lea, D. W. \& Fantle, M. S. Implications of seawater $\mathrm{Mg} / \mathrm{Ca}$ variability for Plio-Pleistocene tropical climate reconstruction. Earth Planet. Sci. Lett. 269, 585-595 (2008). </jrn> 
$<$ jrn $>22$. Williams, I., Pierrehumbert, R. \& Huber, M. Global warming, convective threshold and false thermostats. Geophys. Res. Lett. 36, L21805 (2009). </jrn>

$<$ jrn $>23$. DiNezio, P. N. et al. Climate response of the equatorial pacific to global warming. J. Clim. 22, 4873-4892 (2009). </jrn>

$<$ jrn $>24$. Chandler, M., Rind, D. \& Thompson, R. Joint investigations of the middle Pliocene climate II: GISS GCM Northern Hemisphere results. Global Planet. Change 9, 197-219 (1994). $</$ jrn $>$

$<$ jrn $>25$. Jia, G., Chen, F. \& Peng, P. Sea surface temperature differences between the western equatorial Pacific and northern South China Sea since the Pliocene and their paleoclimatic implications. Geophys. Res. Lett. 35, L18609 (2008). </jrn>

$<\mathrm{jrn}>26$. Li, L. et al. A 4-Ma record of thermal evolution in the tropical western Pacific and its implications on climate change. Earth Planet. Sci. Lett. 309, 10-20 (2011). $</ \mathrm{jrn}>$

$<$ jrn $>27$. deMenocal, P. African climate change and faunal evolution during the Pliocene-Pleistocene. Earth Planet. Sci. Lett. 220, 3-24 (2004).</jrn>

$<$ jrn $>28$. Boccaletti, G., Pacanowski, R., Philander, S. \& Fedorov, A. The thermal structure of the upper ocean. J. Phys. Oceanogr. 34, 888-902 (2004).</jrn>

$<$ jrn $>29$. Fedorov, A. V., Pacanowski, R. C., Philander, S. G. \& Boccaletti, G. The effect of salinity on the wind-driven circulation and the thermal structure of the upper ocean. J. Phys. Oceanogr. 34, 1949-1966 (2004).</jrn>

$<$ jrn $>30 . \quad$ Ford, H. L., Ravelo, A. C. \& Hovan, S. A deep Eastern Equatorial Pacific thermocline during the early Pliocene warm period. Earth Planet. Sci. Lett. 355-356, $152-161(2012) .</$ jrn $>$

<unknown $>31$. Steph, S. et al. Early Pliocene increase in thermohaline overturning: a precondition for the development of the modern equatorial pacific cold tongue. Paleoceanography 25, PA2202 (2010). </unknown> [AUTHOR: Journal article: doi: 10.1029/2008PA001645.] 
$<$ jrn $>$ 32. McCreary, J. \& Lu, P. Interaction between the subtropical and equatorial ocean circulations: the subtropical cell. J. Phys. Oceanogr. 24, 466-497 (1994). $</ \mathrm{jrn}>$

$<\mathrm{jrn}>33$. Haywood, A. M. et al. Comparison of mid-Pliocene climate predictions produced by the HADAM3 and GCMAM3 general circulation models. Global Planet. Change 66, 208-224 (2009). </jrn $>$

$<$ jrn $>34$ L Lunt, D., Foster, G., Haywood, A. \& Stone, E. Late Pliocene Greenland glaciation controlled by a decline in atmospheric $\mathrm{CO}_{2}$ levels. Nature 454, 1102-1105 $(2008) .</ j \mathrm{rn}>$

$<$ jrn $>35$. Maier-Reimer, E., Mikolajewicz, U. \& Crowley, T. Ocean general circulation model sensitivity experiment with an open Central American isthmus.

Paleoceanography 5, 349-366 (1990). $</$ jrn $>$

$<$ jrn $>$ 36. Collins, M. El Niño- or La Niña-like climate change? Clim. Dyn. 24, 89-104 $(2005) .</ j r n>$

$<$ jrn $>37$. Lunt, D. et al. Earth system sensitivity inferred from Pliocene modelling and data. Nature Geosci. 3, 60-64 (2010). </jrn>

$<$ jrn $>38$. Haug, G. \& Tiedemann, R. Effect of the formation of the Isthmus of Panama on Atlantic ocean thermohaline circulation. Nature 393, 673-676 (1998).</jrn>

$<$ unknown $>39$. Molnar, P. Closing of the Central American seaway and the ice age: a critical review. Paleoceanography 23, PA2201 (2008).</unknown> [AUTHOR: Journal article: doi: 10.1029/2007PA001574.]

$<$ jrn $>40$. Zhang, X. et al. Changes in equatorial Pacific thermocline depth in response to Panamanian seaway closure: insights from a multi-model study. Earth Planet. Sci. Lett. 317-318, 76-84 (2012). $<$ jrn $>$

$<$ jrn $>41$. Cane, M. A. \& Molnar, P. Closing of the Indonesian seaway as a precursor to east African aridification around 3-4 million years ago. Nature 411, 157-162 $(2001) .</ j r n>$ 
$<$ jrn $>42$. Jochum, M., Fox-Kemper, B., Molnar, P. \& Shields, C. Differences in the Indonesian Seaway in a coupled climate model and their relevance to Pliocene climate and El Niño. Paleoceanography 24, PA1212 (2009).</jrn>

$<$ jrn $>43$. Barreiro, M. \& Philander, S. G. Response of the tropical Pacific to changes in extratropical clouds. Clim. Dyn. 31, 713-729 (2008). $<$ jrn>

$<$ jrn $>44 . \quad$ Fedorov, A., Brierley, C. \& Emanuel, K. Tropical cyclones and permanent El Niño in the early Pliocene epoch. Nature 463, 1066-1070 (2010). </jrn>

$<$ jrn $>45$. Raymo, M., Grant, B., Horowitz, M. \& Rau, G. Mid-Pliocene warmth: stronger greenhouse and stronger conveyor. Mar. Micropaleontol. 27, 313-326 (1996). $<$ jrn $>$

<jrn>46. Gent, P. R. et al. The Community Climate System Model version 4. J. Clim. 24, 4973-4991 (2011). </jrn>

$<$ jrn>47. Lisiecki, L. E. \& Raymo, M. E. A. Pliocene-Pleistocene stack of 57 globally distributed benthic $\delta^{18} \mathrm{O}$ records. Paleoceanography 20, 1-17 (2005). $<$ jrn $>$

$<\mathrm{jrn}>48$. Haug, G. et al. North Pacific seasonality and the glaciation of North America 2.7 million years ago. Nature 433, 821-825 (2005). $</$ jrn $>$

$<$ unknown $>49$. Shipboard Scientific Party in Proc. ODP Init. Reports. Vol. 162 (eds Jansen, E. et al.) 223-252 (Texas A\&M Univ., 1996).</unknown> [AUTHOR: I believe this is a journal, but possibly a report. Doi: 10.2973/odp.proc.ir.162.107.1996]

Supplementary Information is available in the online version of the paper.

Acknowledgements Financial support was provided by the grants to A.V.F. and K.T.L. from the US National Science Foundation (OCE-0901921 and OCE-0623310), the US Department of Energy Office of Science (DESC0007037) and the David and Lucile Packard Foundation. This work was supported in part by the Yale University Faculty of Arts and Sciences High Performance Computing facility. A.V.F. thanks G. Philander, P. deMenocal, T. Herbert, Y. Rosenthal, A. Haywood, D. Lunt, M. Barreiro, E. Tziperman, D. Battisti, M. Cane and $\mathrm{C}$. Wunsch for discussions of this topic. We are grateful to a great number of scientists who provided the data used in this study.

Author Contributions A.V.F., K.T.L. and C.M.B. coordinated the manuscript and contributed equally to writing the manuscript and to the ideas it contains; K.T.L. compiled the SST data with Z.L. (alkenones) and 
P.S.D. (Mg/Ca). C.M.B. performed the model simulations with A.V.F.; A.V.F. compiled the $\mathrm{CO}_{2}$ data. A.C.R. helped to interpret the data. All authors were involved in the writing at different stages of the work on this manuscript.

Author Information Reprints and permissions information is available at www.nature.com/reprints. The authors declare no competing financial interests. Readers are welcome to comment on the online version of the paper. Correspondence and requests for materials should be addressed to A.V.F (alexey.fedorov@yale.edu).

Figure 1 Climate evolution over the past 5 Myr. a, Variations in benthic $\delta^{18} \mathrm{O}_{\mathrm{PDB}}(\%$ o) $=\left(\left({ }^{18} \mathrm{O} /{ }^{16} \mathrm{O}\right)_{\text {sample }} /\left({ }^{18} \mathrm{O} /{ }^{16} \mathrm{O}\right)_{\mathrm{PDB}}-1\right) * 1000(\mathrm{PDB}$, PeeDee Belemnite $)$ from deep-ocean sediments, showing glacial cycles (light blue) and a long-term trend ${ }^{47}$ (dark blue). $\delta^{18} \mathrm{O}$ records past variations in deep-ocean temperature and global ice volume. The shading highlights the period during which Northern Hemisphere glaciation gradually begins ${ }^{5}$. b, Magnetic susceptibility of ocean sediments in the northern Pacific ${ }^{48}$ (red) and Atlantic ${ }^{49}$ (green). Higher susceptibility indicates the presence of more ice-rafted debris, corresponding to larger Northern Hemisphere ice sheets. ODP, Ocean Drilling Program. c, Proxy $\mathrm{CO}_{2}$ data from marine geochemical studies and ice-core inclusions (Supplementary Table 1). $\mathrm{pCO}_{2}$, atmospheric carbon dioxide concentration. Providing this definition seems like overkill. Pagani wrote and entire paper about pCO2 in a Nature related publication and didn't have to define the fact that pCO2 means atmospheric $\mathrm{CO} 2$ concentration. Uncertainties, indicated by the widths of the data bands, are defined in the respective studies (see Methods for extra references).

\section{Figure 2 Temperature evolution over the past $5 \mathrm{Myr}$ in different regions of the ocean.}

a-d, Trends computed as running means of the original proxy temperature data. Solid lines are 400-kyr running means for records that resolve Milankovitch (orbital) timescales, whereas dashed lines are 600-kyr running means of time series with a coarser resolution. Before computing the running means, all time series were interpolated to a constant spacing of 2 kyr. e, Map of ODP and Deep Sea Drilling Project sites (points) for which the data were generated, superimposed on a map of modern annual mean SST (contours). The original data along with the relevant references are provided in Supplementary Information.

Figure 3 Temperature changes in different regions of the ocean. Relative changes in temperature with respect to the beginning of each trend line. Solid and dashed lines are as in Fig. 2. Note the stability of warm pool temperatures with respect to SST changes in other 
regions of the ocean. For changes computed only for interglacial temperatures, see Supplementary Fig. 2.

Figure 4 Evolution of SST gradients over the past 4-5 Myr. a-c, Meridional SST gradients (in the Pacific and Atlantic) from alkenone SST proxies. d-f, Zonal SST gradient along the Equator in the Pacific from different ODP sites and temperature proxies. Despite the uncertainty in the different reconstructions, they all support the notion of the reduced zonal gradient in the early Pliocene.

Figure 5 Testing mechanisms of Pliocene warmth and reduced temperature gradients. Anomalies in SST $(\mathbf{a}-\mathbf{e})$ and subsurface temperature $(\mathbf{f}-\mathbf{j})$ between the simulated early Pliocene and the preindustrial control. All simulations use a coupled climate model (the NCAR Community Earth System Model) and are identical except for a particular model perturbation: increasing $\mathrm{CO}_{2}$ concentrations by 100 p.p.m. from the preindustrial level (a,f); shifting islands of Indonesia southward (b, g); opening the CAS to a depth of $150 \mathrm{~m}(\mathbf{c}, \mathbf{h})$; increasing ocean mixing in the subtropical bands (d, i); and reducing extratropical cloud albedo $(\mathbf{e}, \mathbf{j})$. Landmasses shaded green were removed in the respective experiments. Thick dashed and solid lines in the right panels show the thermocline depth in the Control and perturbation experiments, respectively.

Figure 6 Global surface air temperature anomalies in two experiments. a, $\mathrm{CO}_{2}$ increase; b, Combined. The Combined experiment includes three different forcings: a 100-p.p.m. $\mathrm{CO}_{2}$ increase, enhanced ocean mixing in the subtropical bands and reduced albedo of low clouds in the extratropics. Note the warming of the eastern equatorial Pacific, a reduction of the temperature gradient between the Equator and the subtropics (also see Supplementary Fig. 11), and a significant warming of high latitudes

\section{METHODS}

\section{SST reconstructions}

Two geochemical proxies, alkenone unsaturation index $\left(U^{K^{\prime}}{ }_{37}\right)$ and $\mathrm{Mg} / \mathrm{Ca}$ ratios of planktonic foraminiferal shells, derived from material preserved in deep-sea sediment, are now widely used to reconstruct ocean temperatures. Alkenones are long-chain ethyl and methyl ketones that vary in the number of double bonds they have and are produced by coccolithophorids living in ocean surface waters. The degree of unsaturation in $\mathrm{C}_{37}$ alkenones 
reflects the temperature of the water in which these organisms lived at the time of production. Owing to their large size relative to other organic compounds, these molecules are resistant to degradation and are therefore well preserved in the sediment record. Several global calibration studies indicate a robust linear calibration between $U^{K^{\prime}} 37$ and ocean surface temperature, confirming the global applicability of a single calibration equation (see ref. 50 for a review). All $U^{K^{\prime}}{ }_{37}$ values reported here are use the calibration from ref. 51 except for ODP site 882 , which, owing to a significant abundance of $\mathrm{C}_{37: 4}$, uses the $U^{K}{ }_{37}$ index as initially reported ${ }^{52}$. Because the dominant producers of $U^{K^{\prime}}{ }_{37}$ in the modern ocean have been present only in the past $200 \mathrm{kyr}$, there was initially concern about the applicability of this proxy on longer timescales. However, numerous studies have shown that changes in $U^{K^{\prime}}{ }_{37}$ are not coincident with shifts in haptophyte algae species ${ }^{53,54}$, indicating that producers of alkenones consistently record surface water conditions.

Planktonic foraminifera secrete their $\mathrm{CaCO}_{3}$ shell in the surface mixed layer, where warmer temperatures cause an exponential increase in the $\mathrm{Mg} / \mathrm{Ca}$ ratio because more $\mathrm{Mg}$ substitutes for $\mathrm{Ca}$ in the shell under warmer conditions. Although shells are commonly well preserved in sediments above the lysocline, partial dissolution of the shells lowers the $\mathrm{Mg}$ content, potentially biasing SST estimates. This bias can be avoided by selecting wellpreserved shell material or by using calibrations that include a correction for dissolution. The calibration used for any given site must be considered individually, as the preservation of the sample material will determine which calibration is most appropriate. We examined the appropriateness of the calibrations used at each site in the original publications, and assessed the sensitivity of the resultant SST estimates to using or not using a dissolution correction where one had not been applied in the original study. In all cases, the differences in calibrations yielded estimates that differed from each other by less than $1^{\circ} \mathrm{C}$. In most cases, the results differed by less than $0.5^{\circ} \mathrm{C}$, suggesting that SST estimates for the sites examined here are not strongly influenced by dissolution.

Four different calibrations were applied to different records in this study (Supplementary Table 3). The main differences between the calibrations are the presence or absence of a dissolution correction and how that dissolution correction is incorporated into the calibration. It is important to note that the calibrations are quite similar if preservation is good. For example, some calibrations use $\Delta \mathrm{CO}_{3}{ }^{2-}$ or core depth to correct for dissolution ${ }^{55}$, 
but if preservation is excellent, and that correction is removed, the calibration is essentially the same as that of ref. 56, which does not include a dissolution correction. Therefore, calibration choice affects the absolute SST estimates but does not change the long-term trends of the records. Given that changing calibrations from those selected in the original publications yields very small differences in the absolute SST estimates and does not affect the long-term trends, we chose to use the originally applied calibrations at all sites except one. The $\mathrm{Mg} / \mathrm{Ca}$ data from ODP site 709 overlap with data from ODP site 806, which is not unexpected given that both sites are in the warm pool and at similar water depths. However, the SSTs reported in ref. 57 are $\sim 1.5^{\circ} \mathrm{C}$ cooler than those from ODP site 806 . This could be because the dissolution correction applied to the data from ODP site 709 is based on core tops from the Caribbean $\mathrm{Sea}^{58}$, which may not be appropriate for an Indian Ocean site, such as site 709 . We chose to apply the same $\Delta \mathrm{CO}_{3}{ }^{2-}$-corrected calibration to ODP site 709 as was used for ODP site 806 because doing so yields a core-top estimate close to modern SST values in the region for ODP site 806 (ODP site 709 does not have core-top data).

It has been suggested that $\mathrm{Mg} / \mathrm{Ca}$ temperature measurements, which provide the majority of the warm pool data, should be corrected for secular changes in seawater composition $^{21}$. However, the general agreement between $\mathrm{Mg} / \mathrm{Ca}$ and alkenone records in locations where both techniques are applicable indicates that this correction should be small, of the order of calibration errors ${ }^{12}$, and it is therefore not applied here.

Finally, we have chosen to omit $\mathrm{Mg} / \mathrm{Ca}$ records from sites 999 and 1000 located in the Caribbean Sea, because these records do not clearly reflect open-ocean conditions ${ }^{59}$. We have also omitted site 1241 from our analysis, because this site has moved considerably tectonically (the SST at its present location is $\sim 1.4{ }^{\circ} \mathrm{C}$ higher than that at its Pliocene latitude). Additionally, the $\mathrm{Mg} / \mathrm{Ca}$ calibration used in the original publication ${ }^{60}$ is based on a culturing study that excludes a dissolution correction, which we feel should be incorporated at this location.

The trends are computed as 400-kyr or 600-kyr running means for each temperature record, which were resampled to a 2-kyr spacing before computing the means (the original data are included in Supplementary Information). This approach filters out glacialinterglacial variability and highlights first-order trends in these records. Comparative analysis 
of different resampling resolutions and window sizes demonstrates that the first-order results reported here are insensitive to changes in these parameters.

Computing the trends as we do in the main part of the paper, incorporating both glacial and interglacial intervals of the time series, is conventional in palaeoclimatology. Nevertheless, some of the inferences in this study actually concern differences between the late Quaternary interglacials and Pliocene interglacials. Therefore, to make sure that our conclusions about the structural climate change are robust regardless of how we compute the trends, we have compared the mean trends and those based just on interglacial intervals of the time series.

The procedure for calculating 'interglacial' trends includes several steps. First, each time series is divided into separate intervals (bins). Typically, we choose bins of 41-kyr length, which corresponds to the dominant spectral component of the glacial cycles of the past 5 Myr (the one related to variations in Earth's obliquity). Longer intervals are chosen for coarse time series. For each bin, we find the point with the maximum temperature and then interpolate these temperatures on the original grid of the time series. Finally, to compute the new trends, we apply 400-kyr or 600-kyr running means to the new record. This procedure picks up maximum interglacial temperatures as well as points with relatively warm temperatures but lying outside the actual interglacials (specifically, those belonging to the warm interstadials of the past $1 \mathrm{Myr}$ ). We choose to retain such points because many of them are as warm as modern temperatures and also because we prefer to use bins of the same size throughout the entire length of the time series. Very rarely does this procedure pick up cold points erroneously, but the effect of such errors is minimized by computing the running means. Using larger bins, $80 \mathrm{kyr}$ for example, would eliminate most of these points and raise the trend lines by a few tenths of a degree Celsius on average.

As expected, the mean temperatures computed for interglacials (Supplementary Fig. 1) turn out to be $\sim 1^{\circ} \mathrm{C}$ warmer than those computed for the full time series, but the relative temperature changes (Supplementary Fig. 2) are remarkably similar between the two methods, with differences typically below $0.5^{\circ} \mathrm{C}$, which confirms the robustness of our main conclusions. 
The SST data are grouped into four broad categories: waters of low-latitude warm pools $^{11,57,61-63}$ (Supplementary Fig. 4); upwelling zones in the deep tropics ${ }^{11,14,64-68}$, including equatorial upwelling sites and the Arabian Sea (Supplementary Fig. 5); subtropical coastal upwelling regions ${ }^{10,20,65,69-71}$ (Supplementary Fig. 6); mid and high latitudes ${ }^{14,15,52,62,70,72-74}$ (Supplementary Fig. 7). There are two sites in the South China Sea that currently lie outside the warm pool ${ }^{25,26,75}$, but they seem to have been contained within it earlier (Supplementary Figs 8 and 9). The high productivity at upwelling locations makes them especially suitable for the creation of continuous records over the past $5 \mathrm{Myr}$, hence their prominence in this compilation. See Supplementary Information for both the full and the temporally averaged data.

\section{Data uncertainty and error bars}

The two SST proxies we use ( $\mathrm{Mg} / \mathrm{Ca}$ and $\left.U^{K^{\prime}}{ }_{37}\right)$ are widely applied in palaeoceanographic studies, but each carries inherent uncertainties. Although some uncertainties, such as ecological shifts for the $U^{K^{\prime}}{ }_{37}$ values and changes in seawater chemistry for $\mathrm{Mg} / \mathrm{Ca}$ values, are difficult to quantify, several studies have now demonstrated that these are probably minor and that both proxies are reliable on Pliocene-Pleistocene timescales ${ }^{12,50}$. Also, although the $U^{K^{\prime}}{ }_{37}$ index is insensitive to temperature change above $\sim 29^{\circ} \mathrm{C}$, only three of the records included here reach this threshold value, and do so only for short durations. Comparison between these records and other SST proxies from the same sites indicates that temperatures during theses times were probably only marginally warmer than the threshold value, which should not affect the conclusions reached in this paper. Because analytical precision is excellent for both types of measurements, the dominant source of error in converting the primary data to SST estimates is in the calibration used. The calibration errors can be propagated to provide an estimate of the errors for each type of data.

Although a detailed error analysis of each of the previously published proxy records included in this study is beyond the scope of this paper, we nonetheless compare four records from the tropical Pacific Ocean (Supplementary Fig. 10). The $\mathrm{Mg} / \mathrm{Ca}$ and $U^{K^{\prime}}{ }_{37}$ records at ODP site 847 have previously been compared in detail ${ }^{13}$, and here we compare those records from the eastern equatorial Pacific (EEP) with $\mathrm{Mg} / \mathrm{Ca}$ and $U^{K^{\prime}}{ }_{37}$ records from ODP site 806 in the western equatorial Pacific ${ }^{11,62}$ (WEP). Because the data were not measured on the same 
samples within each core, and because of the different time resolutions of the data, we separated the data into 400-kyr bins. This bin size allows for reliable statistics but is not so large that any one bin encompasses a large portion of the long-term trends.

For both the $\mathrm{Mg} / \mathrm{Ca}$ and $U^{K^{\prime}}{ }_{37}$, the analytical error is essentially negligible and the dominant source of error is the calibration used to convert the primary data to a SST estimate. To assess the uncertainty in SST estimates $\left(\sigma_{\mathrm{SST}}\right)$, we propagated the uncertainties in the parameters of the proxy calibrations. For example, for $U^{K^{\prime}}{ }_{37}$ the linear calibration is $\operatorname{SST}_{U^{K^{\prime}}}=\frac{U^{K^{\prime}}}{b}-\frac{a}{b}$

The uncertainties in $a\left(\sigma_{a}\right)$ and $b\left(\sigma_{b}\right)$ are reported in the original calibration, and can be propagated for each data point as follows:

$$
\sigma_{\mathrm{SST}}^{2}=\sigma_{a}^{2}\left(\frac{\partial \mathrm{SST}}{\partial a}\right)^{2}+\sigma_{b}^{2}\left(\frac{\partial \mathrm{SST}}{\partial b}\right)^{2}+\sigma_{U^{K^{\prime}}{ }_{37}}^{2}\left(\frac{\partial \mathrm{SST}}{\partial U^{K^{\prime}}}\right)^{2}
$$

The same process was done for the $\mathrm{Mg} / \mathrm{Ca}$ calibration (the same $\mathrm{Mg} / \mathrm{Ca}$ calibration was used in the WEP and the EEP). The average propagated errors for $U^{K^{\prime}}{ }_{37}$ are $1.6^{\circ} \mathrm{C}$, for ODP sites 847 and 806 , and $1.7{ }^{\circ} \mathrm{C}$ and $1.9^{\circ} \mathrm{C}$, for ODP sites 847 and 806 , respectively. The error bars in Supplementary Fig. 10 represent the uncertainties in the means calculated for each bin, given the propagated errors described above, calculated as

$$
\sigma_{\text {mean SST }}^{2}=\sigma_{\text {SST }} / \sqrt{N}
$$

We note that the errors for $U^{K^{\prime}}{ }_{37}$ at ODP site 806 are larger owing to the lower-resolution data.

Propagating the error in the calibration demonstrates several important points. First, the $\mathrm{Mg} / \mathrm{Ca}$ and $U^{K^{\prime}}{ }_{37}$ records agree remarkably well in both the WEP and the EEP, in terms of both the long-term trend and the absolute temperature estimates. In the EEP, both records show a cooling by $3-4^{\circ} \mathrm{C}$ over the last $4 \mathrm{Myr}$, and the error bars of the most recent three bins do not overlap with the errors of the oldest three bins, indicating that the EEP was significantly colder in the Pleistocene than during the early Pliocene climactic optimum. The situation is strikingly different in the WEP, where both $\mathrm{Mg} / \mathrm{Ca}$ and $U^{K^{\prime}}{ }_{37}$ indicate that SST in the early Pliocene climatic optimum was not significantly warmer than the Pleistocene. Thus, 
the errors demonstrate that at both sites the two proxies, which have different sources of potential bias, agree remarkably well (Supplementary Fig. 10). This exercise confirms that SST estimates for the eastern and western tropical Pacific indeed overlap during the early Pliocene, although there is a clear gradient between the two locations in the Pleistocene.

In addition, although there are uncertainties in absolute SST values for the Pliocene, planktonic foraminiferal assemblages and the $\delta^{18} \mathrm{O}$ of surface and subsurface planktonic foraminifera were also similar in the western and eastern equatorial Pacific (refs 30, 76 and references therein), providing strong supporting evidence for the reduced east-west gradients in oceanographic conditions during that time.

\section{Sensitivity experiments}

All of the pertinent hypotheses, some tested in idealized or more comprehensive models before, have been re-examined within a single modelling framework to allow a better comparison of their relative impacts. This framework is based on the latest version of the NCAR Community Earth System Model $^{46}$ (CESM) at its relatively low resolution, which facilitates palaeoclimate simulations ${ }^{77}$. The model incorporates an atmospheric model and a land surface model with a spectral truncation of T31 (CAM4 and CLM) coupled to ocean and sea-ice components with a nominal $3^{\circ}$ resolution (POP2 and CICE, respectively). The model has a cold bias that is especially pronounced in the $\operatorname{Arctic}^{77}$.

The previous version of the model (CCSM3) has been used extensively for climate simulations that contributed, for example, to the IPCC Fourth Assessment Report ${ }^{16}$; simulations with CESM will contribute to the next report. Further information about the model, including its source code and the boundary conditions are freely accessible via http://www.cesm.ucar.edu/models/cesm1.0. We use subversion 1.0.2, because earlier versions of the model were not scientifically validated at the low resolution. All the integrations start from a pre-existing preindustrial simulation ${ }^{77}$ (available as b40.037 from http://www.cesm.ucar.edu/models/cesm1.0) and have been integrated for a further $500 \mathrm{yr}$ (including the preindustrial control). This is sufficient for the upper ocean to reach equilibrium with the deep ocean experiencing a weak residual drift. All simulations have orography, vegetation type and land-ice cover prescribed at preindustrial conditions and are designed to assess the roles of separate mechanisms rather than to reproduce the early 
Pliocene climate exactly. Previous work ${ }^{37}$ shows that modifying these factors as appropriate for the Pliocene may increase global mean temperature by $\sim{ }^{\circ} \mathrm{C}$, but contributes little to the structural climate change described here. Figures 5 and 6 show the difference in the averaged climate over the final 25 years from this control simulation.

Each numerical experiment examines the effects of a single type of perturbation with respect to the preindustrial baseline simulation (control), except for the final experiment, which combines three different perturbations. Supplementary Table 4 lists all the experiments and the simulated changes in global mean surface air temperature and temperature variances. The other details of the simulations are described below.

The $\mathrm{CO}_{2}$ experiment involves an instantaneous increase in atmospheric $\mathrm{CO}_{2}$ concentration from 285 p.p.m. to 385 p.p.m., leading to an increase of $1{ }^{\circ} \mathrm{C}$ in global mean air temperature. It is significant that the base model has an equilibrium climate sensitivity of $2.9^{\circ} \mathrm{C}$ (ref. 78), in the middle of the typical range of model climate sensitivities.

Bathymetric perturbations in the ocean gateway experiments involve the removal of five land points (coloured green in Fig. 5). In the shallow-CAS experiment, the bathymetry has been lowered to $150 \mathrm{~m}$. In the other experiments, the bathymetry has been lowered to that of the model's nearby open ocean: $580 \mathrm{~m}$ for the Indonesia experiment and 1,100 m for the deep-CAS experiment. The latter experiment shows the maximum possible signal of this particular tectonic change. Modified boundary conditions for the tectonic simulations can be provided on request. Variations of this experiment that have been performed previously were collated in ref. 40. Supplementary Fig. 12 shows how the SST changes in the present simulations compare with their compilation.

In the enhanced ocean mixing experiment, the hurricane-induced mixing is treated as an increase in background vertical diffusivity of $1 \mathrm{~cm}^{2} \mathrm{~s}^{-1}$ in two subtropical bands $\left(8^{\circ} \mathrm{N}-\right.$ $40^{\circ} \mathrm{N}$ and $8^{\circ} \mathrm{S}-40^{\circ} \mathrm{S}$ ) at depths down to the model level at $185 \mathrm{~m}$ (ref. 44; Supplementary Fig. 13b). The value of $1 \mathrm{~cm}^{2} \mathrm{~s}^{-1}$ was chosen as it is the annual mean diffusivity observed in regions of strong tropical cyclone activity ${ }^{79}$. A recent study shows that imposing permanent mixing in the upper ocean has a largely similar effect as a transient mixing ${ }^{80}$.

In the reduced-cloud-albedo experiment, the cloud liquid water path has been reduced by $20 \%$ polewards of $30^{\circ} \mathrm{N}$ and $30^{\circ} \mathrm{S}$, but only for the purposes of calculating the shortwave 
radiation. This acts to reduce the albedo of highly reflective low stratus clouds (Supplementary Fig. 13a). As a result, global mean air surface temperature increases by $1.1^{\circ} \mathrm{C}$ (Supplementary Table 4). One of the effects of this modification was an increase of $0.7^{\circ} \mathrm{C}$ in the tropical West Pacific SST, which stopped us from imposing a greater reduction. We note that in this experiment we do not directly prescribe changes in cloud albedo, which is calculated within the CESM. This is a different approach from that used to investigate sensitivity to cloud properties in ref. 43. Those authors used a coupled model of intermediate complexity with a specified cloud cover, which they reduced by $50 \%$ in their perturbation experiments. We simulated a range of reduced liquid-water-paths, with $20 \%$ leading to the representation closest to that of ref. 43. The actual reduction in the early Pliocene, if any, is largely unconstrained.

We note that the effects of changes in extratropical low clouds and enhanced ocean mixing on tropical climate seem to be robust in a variety of models. New experiments are now being conducted with high-resolution versions of CESM and other coupled models, which seem to confirm our previous conclusions (to be reported elsewhere).

Among hypotheses that we have not tested, we should mention atmospheric superrotation $^{81}$. In such a state, common on gas giants such as Jupiter, atmospheric Rossby waves radiate polewards from the tropics, generating westerly winds along the Equator and suppressing equatorial upwelling. Recent studies ${ }^{82}$, however, indicate that superrotation develops only at temperatures in excess of $40{ }^{\circ} \mathrm{C}$. It has also been argued that a stronger meridional salinity gradient (with more fresh water in the northern Pacific) could reduce oceanic meridional density gradient and collapse the tropical thermocline ${ }^{83,84}$. This would require a strong increase in precipitation in high latitudes, for which evidence has yet to be found.

\section{Carbon dioxide estimates}

The $\mathrm{CO}_{2}$ estimates are calculated using a variety of techniques based on carbon isotopes ${ }^{45}$, boron isotopes $^{85-87}$, alkenones ${ }^{62,87}$, boron/calcium ratios ${ }^{88}$, stomata $^{89}$ and ice-core inclusions $^{90-92}$ (Supplementary Table 1). They are presented as originally published except for the record based on $\delta^{13} \mathrm{C}$ (ref. 45), which was adjusted to subtract an offset (90 p.p.m.) between the original data and the Antarctic $\mathrm{CO}_{2}$ records. 
$<$ bok $>$ 50. $\quad$ Lawrence, K. T., Herbert, T. D., Dekens, P. S. \& Ravelo, A. in Deep-Time Perspectives on Climate Change: Marrying the Signal from Computer Models and Biological Proxies (eds Williams, M., Haywood, A. M., Gregory, F. J. \& Schmidt, D. N.) $539-562$ (Geol. Soc., 2007). </bok $>$

<jrn>51. Müller, P., Kirst, G., Ruhland, G., von Storch, I. \& Rosell-Melé, A.

Calibration of the alkenone paleotemperature index $\mathrm{U}^{\mathrm{K}}{ }_{37}$ based on core-tops from the eastern South Atlantic and the global ocean $\left(60^{\circ} \mathrm{N}-60^{\circ} \mathrm{S}\right)$. Geochim. Cosmochim. Acta 62, 1757-1772 (1998). </jrn>

<jrn>52. Martínez-Garcia, A., Rosell-Melé, A., McClymont, E. L., Gersonde, R. \& Haug, G. H. Subpolar link to the emergence of the modern equatorial pacific cold tongue. Science 328, 1550-1553 (2010). $</ \mathrm{jrn}>$

<jrn>53. McClymont, E. L., Rosell-Melé, A., Giraudeau, J., Pierre, C. \& Lloyd, J. M. Alkenone and coccolith records of the mid-Pleistocene in the south-east Atlantic: implications for the index and south African climate. Quat. Sci. Rev. 24, 1559-1572 $(2005) .</ j \mathrm{rn}>$

$<$ jrn>54. Müller, P. J., Cepek, M., Ruhland, G. \& Schneider, R. R. Alkenone and coccolithophorid species changes in late quaternary sediments from the Walvis ridge: implications for the alkenone paleotemperature method. Palaeogeogr.

Palaeoclimatol. Palaeoecol. 135, 71-96 (1997). </jrn>

$<$ jrn $>55$. Dekens, P., Lea, D., Pak, D. \& Spero, H. Core top calibration of $\mathrm{Mg} / \mathrm{Ca}$ in tropical foraminifera: refining paleotemperature estimation. Geochem. Geophys. Geosyst. 3, 1-29 (2002).</jrn>

$<$ jrn $>56$. Anand, P., Elderfield, H. \& Conte, M. Calibration of $\mathrm{Mg} / \mathrm{Ca}$ thermometry in planktonic foraminifera from a sediment trap time series. Paleoceanography 18, 1050 (2003). $</$ jrn $>$ [AUTHOR: please add full page range. It's not applicable AGU seems to have adopted an numbering system this year. The article is 15 pages long, but the subsequent article is Diffenbaugh et al supposedly on p1051. CB.]

$<$ unknown $>57$. Karas, C., Nürnberg, D., Tiedemann, R. \& Garbe-Schönberg, D. Pliocene Indonesian throughflow and Leeuwin current dynamics: implications for 
Indian Ocean polar heat flux. Paleoceanography 26, PA2217 (2011).</unknown> [AUTHOR: This is a journal article with a doi of 10.1029/2010PA001949]

$<\mathrm{jrn}>58$. Regenberg, M. et al. Assessing the effect of dissolution on planktonic foraminiferal $\mathrm{Mg} / \mathrm{Ca}$ ratios: evidence from Caribbean core tops. Geochem. Geophys. Geosyst. 7, Q07P15 (2006).</jrn> [AUTHOR: please add full page range. Again it's not applicable - AGU seems to have adopted a different numbering system this year. The article has 23 pages if that helps. CB.]

$<\mathrm{jrn}>59$. Groeneveld, J. et al. Foraminiferal $\mathrm{Mg} / \mathrm{Ca}$ increase in the Caribbean during the Pliocene: western Atlantic warm pool formation, salinity influence, or diagenetic overprint. Geochem. Geophys. Geosyst. 9, Q01P23 (2008).</jrn>

$<$ ths $>60$. Groeneveld, J. Effect of the Pliocene Closure of the Panamanian Gateway on Caribbean and east Pacific Sea Surface Temperatures and Salinities by Applying Combined $\mathrm{Mg} / \mathrm{Ca}$ and ${ }^{18} \mathrm{O}$ Measurements (5.6-2.2 Ma). PhD thesis, Univ. Kiel (2005). $</$ ths $>$ [AUTHOR: please give relevant page range unless whole thesis was used. The relevant pages are 9-14.]

$<$ jrn $>61$. de Garidel-Thoron, T., Rosenthal, Y., Bassinot, F. \& Beaufort, L. Stable sea surface temperatures in the western Pacific warm pool over the past 1.75 million years. Nature 433, 294-298 (2005). </jrn>

$<$ jrn $>$ 62. Pagani, M., Liu, Z., LaRiviere, J. \& Ravelo, A. High earth-system climate sensitivity determined from Pliocene carbon dioxide concentrations. Nature Geosci. 3, 27-30 (2010). </jrn>

$<$ jrn $>63$. Karas, C. et al. Mid-Pliocene climate change amplified by a switch in Indonesian subsurface throughflow. Nature Geosci. 2, 434-438 (2009).</jrn>

$<$ jrn $>$ 64. Etourneau, J., Martinez, P., Blanz, T. \& Schneider, R. Pliocene-Pleistocene variability of upwelling activity, productivity, and nutrient cycling in the Benguela region. Geology 37, 871-874 (2009).</jrn>

$<$ unknown $>65$. Dekens, P. S., Ravelo, A. C. \& McCarthy, M. D. Warm upwelling regions in the Pliocene warm period. Paleoceanography 22, PA3211 
(2007). $</$ unknown $>$ [AUTHOR: This is a journal article. Doi is

10.1029/2006PA001394.]

$<$ jrn $>66$. Liu, Z. \& Herbert, T. D. High-latitude influence on the eastern equatorial Pacific climate in the early Pleistocene epoch. Nature 427, 720-723 (2004). $<$ jrn $>$

$<$ jrn>67. Herbert, T., Peterson, L., Lawrence, K. \& Liu, Z. Tropical ocean temperatures over the past 3.5 million years. Science 328, 1530-1534 (2010). $</$ jrn $>$

$<$ unknown $>68$. Cleaveland, L. C. \& Herbert, T. D. Coherent obliquity band and heterogeneous precession band responses in early Pleistocene tropical sea surface temperatures. Paleoceanography 22, PA2216 (2007). </unknown> [AUTHOR: This is a journal article. Doi is 10.1029/2006PA001370.]

$<$ jrn $>69$. Etourneau, J., Martinez, P., Blanz, T. \& Schneider, R. Intensification of the Walker and Hadley atmospheric circulations during the Pliocene-Pleistocene climate transition. Earth Planet. Sci. Lett. 297, 103-110 (2010).</jrn>

$<\mathrm{jrn}>70$. LaRiviere, J. et al. Late Miocene decoupling of oceanic warmth and atmospheric carbon dioxide forcing. Nature 486, 97-100 (2012). </jrn>

$<\mathrm{edb}>71$. Herbert, T. D. \& Schuffert, J. Alkenone unsaturation estimates of late Miocene through late Pliocene sea surface temperature changes, ODP site 958. Proc. ODP Sci. Res. 159T, 17-22 (1998). </edb>

$<$ unknown>72. Martínez-Garcia, A. et al. Links between iron supply, marine productivity, sea surface temperature, and $\mathrm{CO}_{2}$ over the last $1.1 \mathrm{Ma}$.

Paleoceanography 24, PA1207 (2009). </unknown> [AUTHOR: This is a journal article. Doi is 10.1029/2008PA001657.]

$<$ jrn $>$ 73. Lawrence, K., Sosdian, S., White, H. \& Rosenthal, Y. North Atlantic climate evolution through the Plio-Pleistocene climate transitions. Earth Planet. Sci. Lett. 300, 329-342 (2010). $</$ jrn $>$

$<$ jrn>74. Karas, C., Nürnberg, D., Tiedemann, R. \& Garbe-Schönberg, D. Pliocene climate change of the southwest Pacific and the impact of ocean gateways. Earth Planet. Sci. Lett. 301, 117-124 (2011). </jrn> [AUTHOR: this reference does not 
seem to be cited. Please either delete it or cite it explicitly in the online Methods.

Added citation next to refs 72 and 73 - CB.]

$<$ jrn $>$ 75. Tian, J. et al. Late Pliocene monsoon linkage in the tropical South China Sea.

Earth Planet. Sci. Lett. 252, 72-81 (2006). </jrn>

$<$ jrn $>$ 76. Ravelo, A. Walker circulation and global warming: lessons from the geologic past. Oceanography 19, 114-122 (2006). $<$ jirn>

$<$ jrn $>$ 77. Shields, C. A. et al. The low resolution CCSM4. J. Clim. 25, 3993-4014 $(2012) .</ j \mathrm{rn}>$

$<\mathrm{jrn}>78$. Bitz, C. M. et al. Climate sensitivity of the Community Climate System Model version 4. J. Clim. 25, 3053-3070 (2012). </jrn>

$<$ jrn $>$ 79. Sriver, R. L. \& Huber, M. Observational evidence for an ocean heat pump induced by tropical cyclones. Nature 447, 577-580 (2007). </jrn>

$<$ jrn $>$ 80. Manucharyan, G., Brierley, C. \& Fedorov, A. Climate impacts of intermittent upper ocean mixing induced by tropical cyclones. J. Geophys. Res. 116, C11038 $(2011) .</ j \mathrm{rn}>$

$<$ unknown $>81$. Tziperman, E. \& Farrell, B. Pliocene equatorial temperature: lessons from atmospheric superrotation. Paleoceanography 24, PA1101 (2009).</unknown> [AUTHOR: This is a journal article. Doi is 10.1029/2008PA001652.]

$<$ jrn $>82$. Caballero, R. \& Huber, M. Spontaneous transition to superrotation in warm climates simulated by cam3. Geophys. Res. Lett. 37, L11701 (2010).</jrn>

$<$ jrn $>$ 83. Fedorov, A., Barreiro, M., Boccaletti, G., Pacanowski, R. \& Philander, S. The freshening of surface waters in high latitudes: effects on the thermohaline and winddriven circulations. J. Phys. Oceanogr. 37, 896-907 (2007).</jrn>

$<\mathrm{jrn}>84$. McKay, R. et al. Antarctic and Southern Ocean influences on late Pliocene global cooling. Proc. Natl Acad. Sci. USA 109, 6423-6428 (2012).</jrn>

$<$ bok $>85$. Bartoli, G., Hönisch, B. \& Zeebe, R. E. Atmospheric $\mathrm{CO}_{2}$ decline during the Pliocene intensification of Northern Hemisphere glaciations. Paleoceanography 26, 
PA4213 (2011). $</$ bok $>$ [AUTHOR: This is a journal article. Doi is 10.1029/2010PA002055.]

<jrn>86. Hönisch, B., Hemming, N. G., Archer, D., Siddall, M. \& McManus, J. F.

Atmospheric carbon dioxide concentration across the mid-Pleistocene transition. Science 324, 1551-1554 (2009). $</$ jrn $>$

$<\mathrm{jrn}>$ 87. Seki, O. et al. Alkenone and boron-based Pliocene $\mathrm{pCO}_{2}$ records. Earth

Planet. Sci. Lett. 292, 201-211 (2010).</jrn>

$<$ jrn $>$ 88. Tripati, A. K., Roberts, C. D. \& Eagle, R. A. Coupling of $\mathrm{CO}_{2}$ and ice sheet stability over major climate transitions of the last 20 million years. Science 326, 1394-1397 (2009).</jrn>

<jrn>89. Kürschner, W. M., van der Burgh, J., Visscher, H. \& Dilcher, D. L. Oak leaves as biosensors of late Neogene and early Pleistocene paleoatmospheric $\mathrm{CO}_{2}$ concentrations. Mar. Micropaleontol. 27, 299-312 (1996). $</$ jrn $>$

$<\mathrm{jrn}>90$. Petit, J. et al. Climate and atmospheric history of the past 420,000 years from the Vostok ice core, Antarctica. Nature 399, 429-436 (1999). </jrn>

$<$ jrn $>91$. Siegenthaler, U. et al. Stable carbon cycle-climate relationship during the late Pleistocene. Science 310, 1313-1317 (2005). </jrn>

$<$ jrn $>92$ L Lüthi, D. et al. High-resolution carbon dioxide concentration record 650,000800,000 years before present. Nature 453, 379-382 (2008).</jrn> 


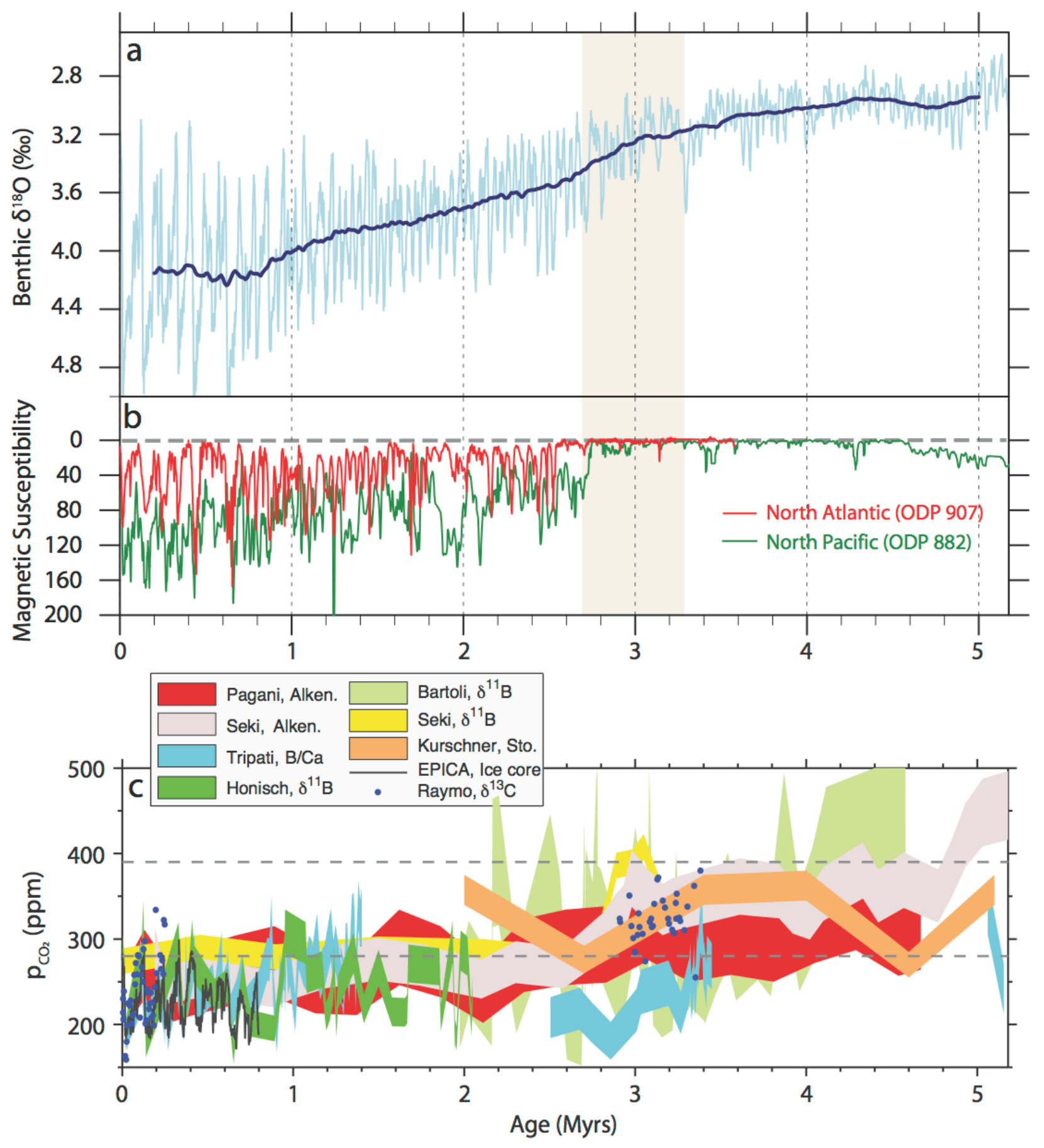

Figure 1 


\section{Temperature Trends}
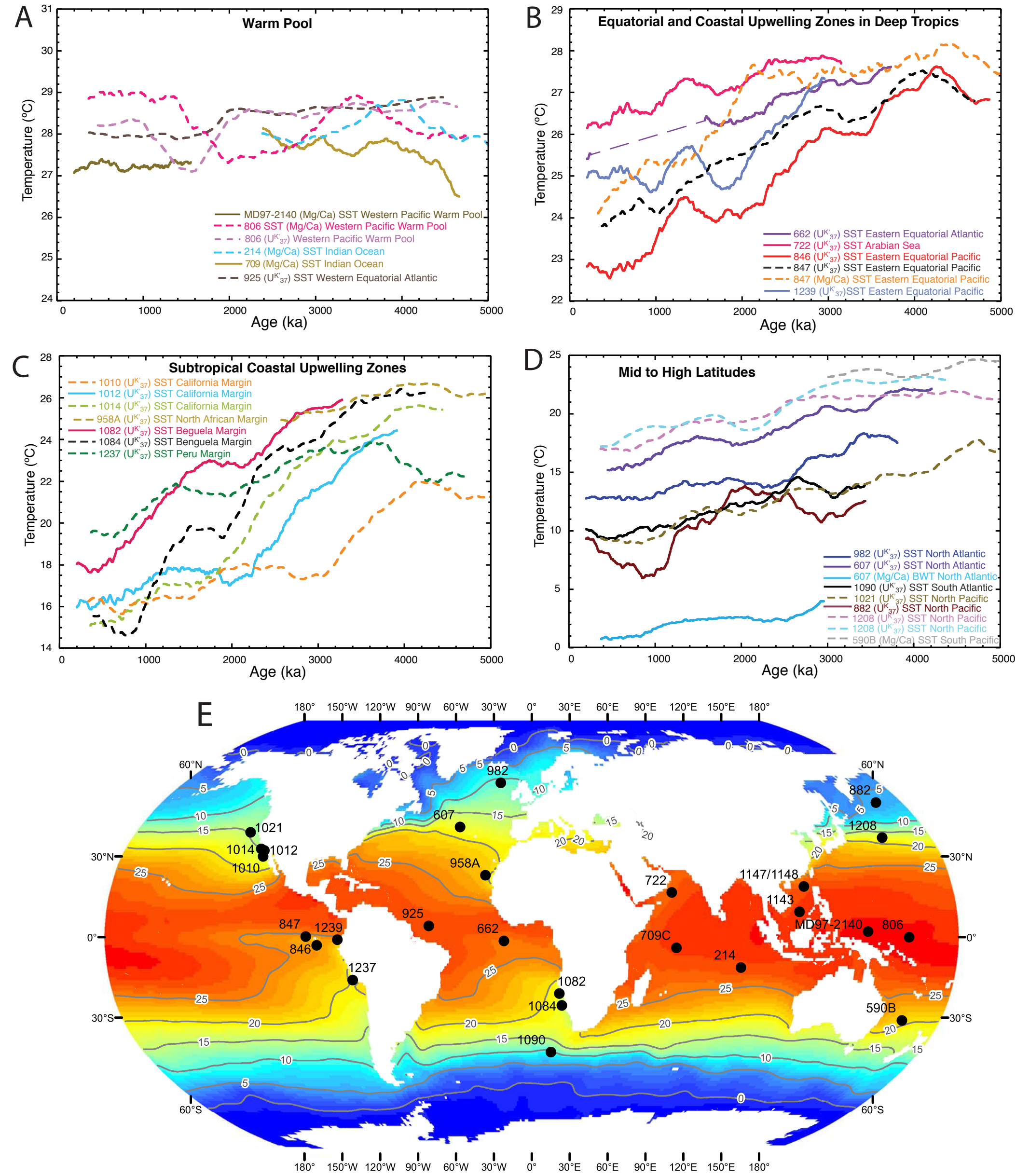

Temperature (C)

Figure 2

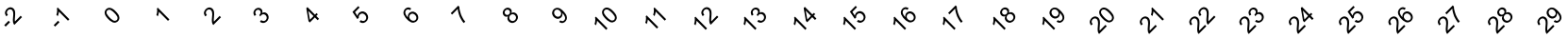


a Meridional SST Gradients

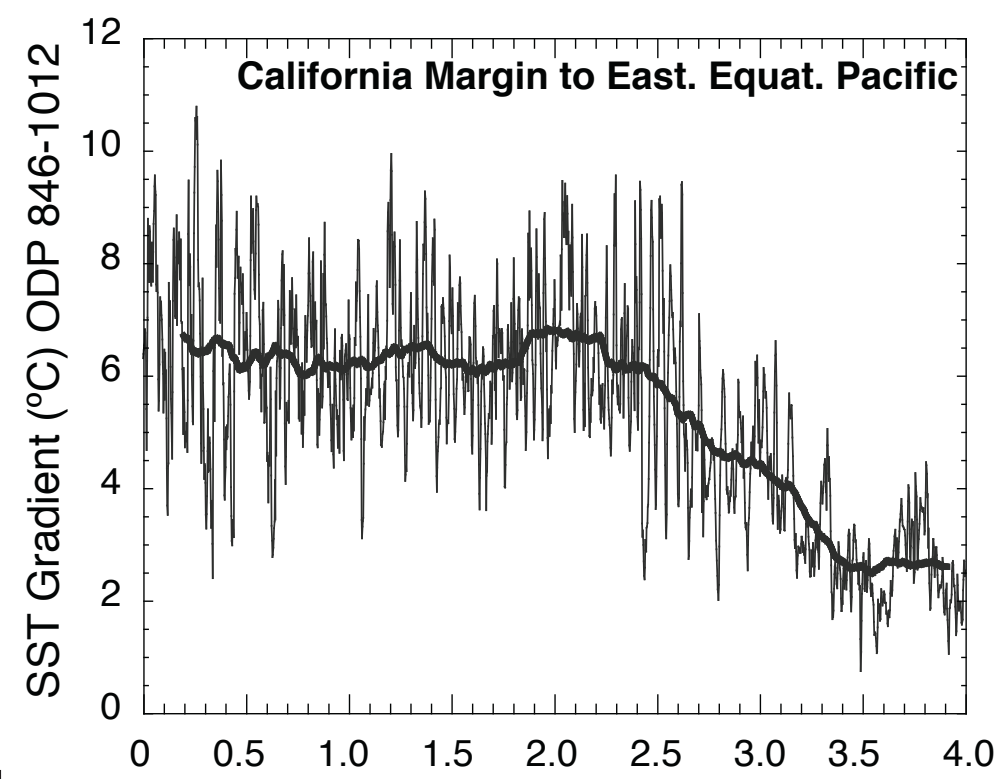

b

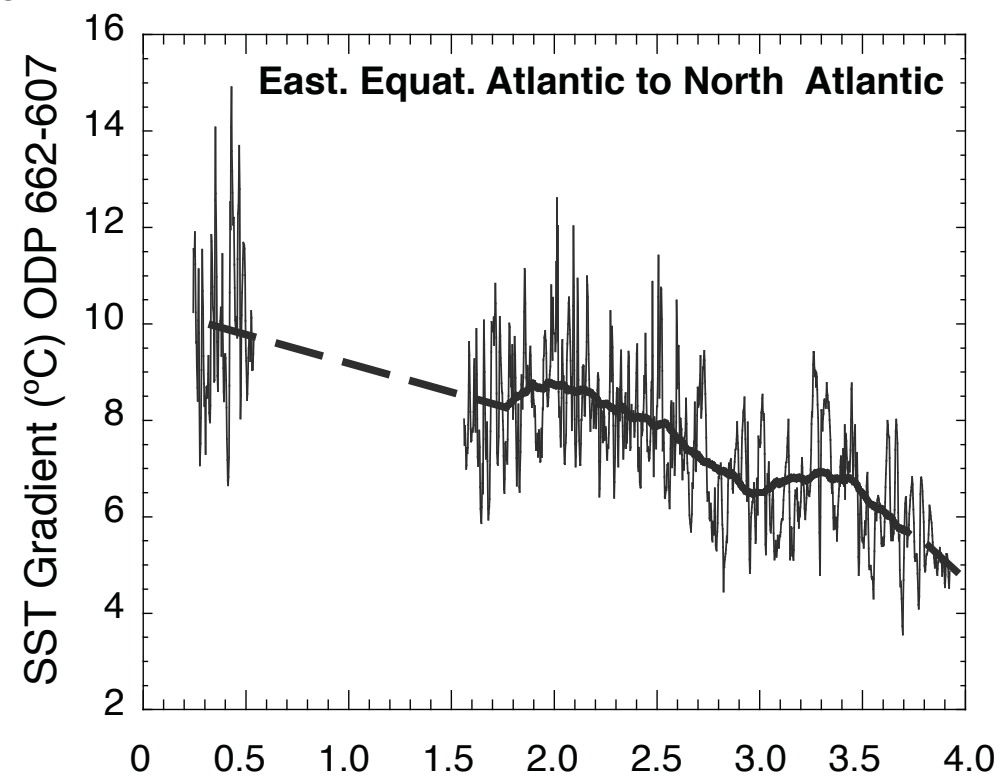

C

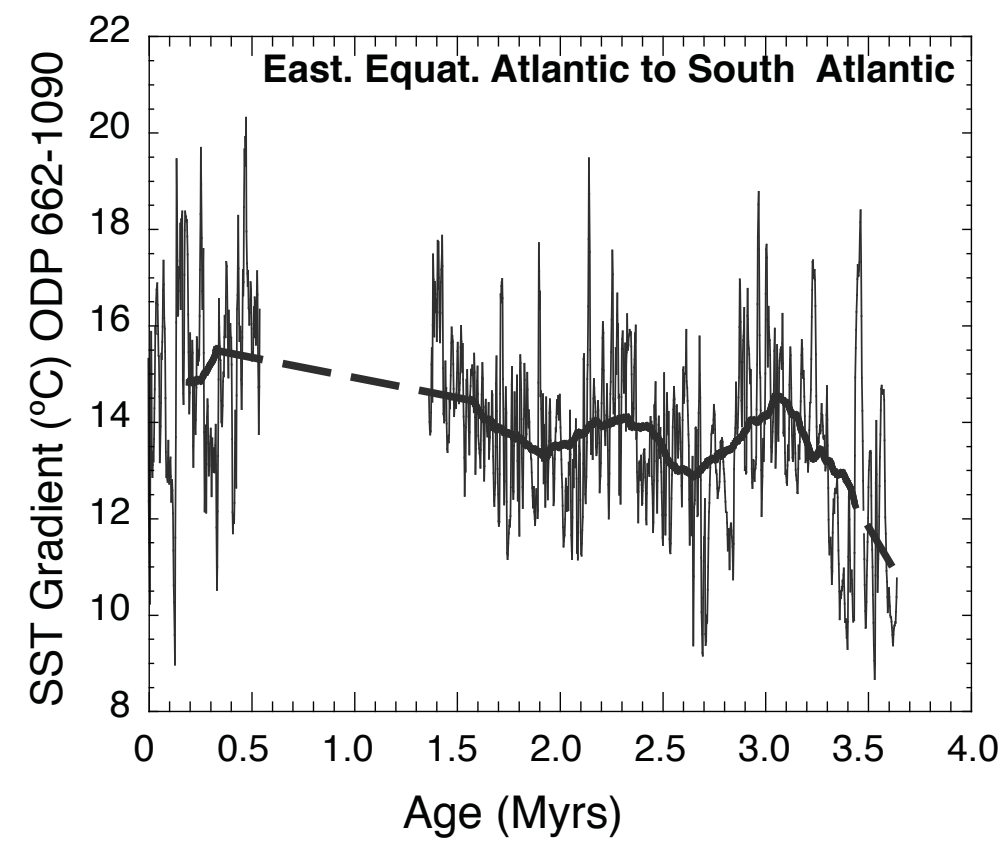

Zonal SST Gradients

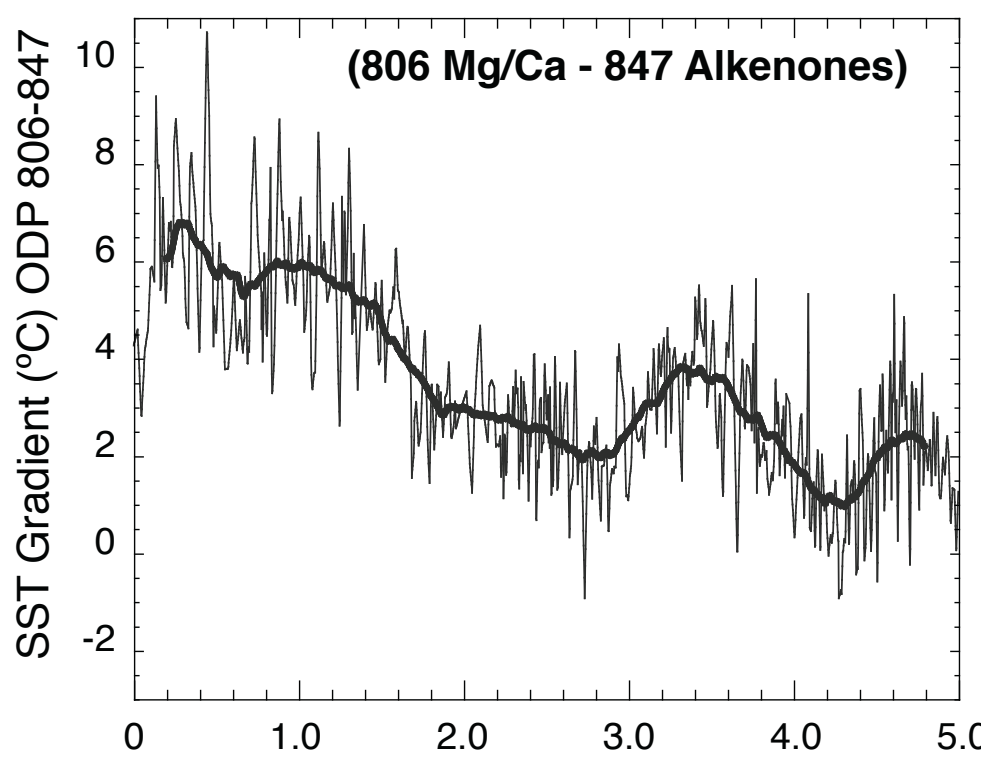

e
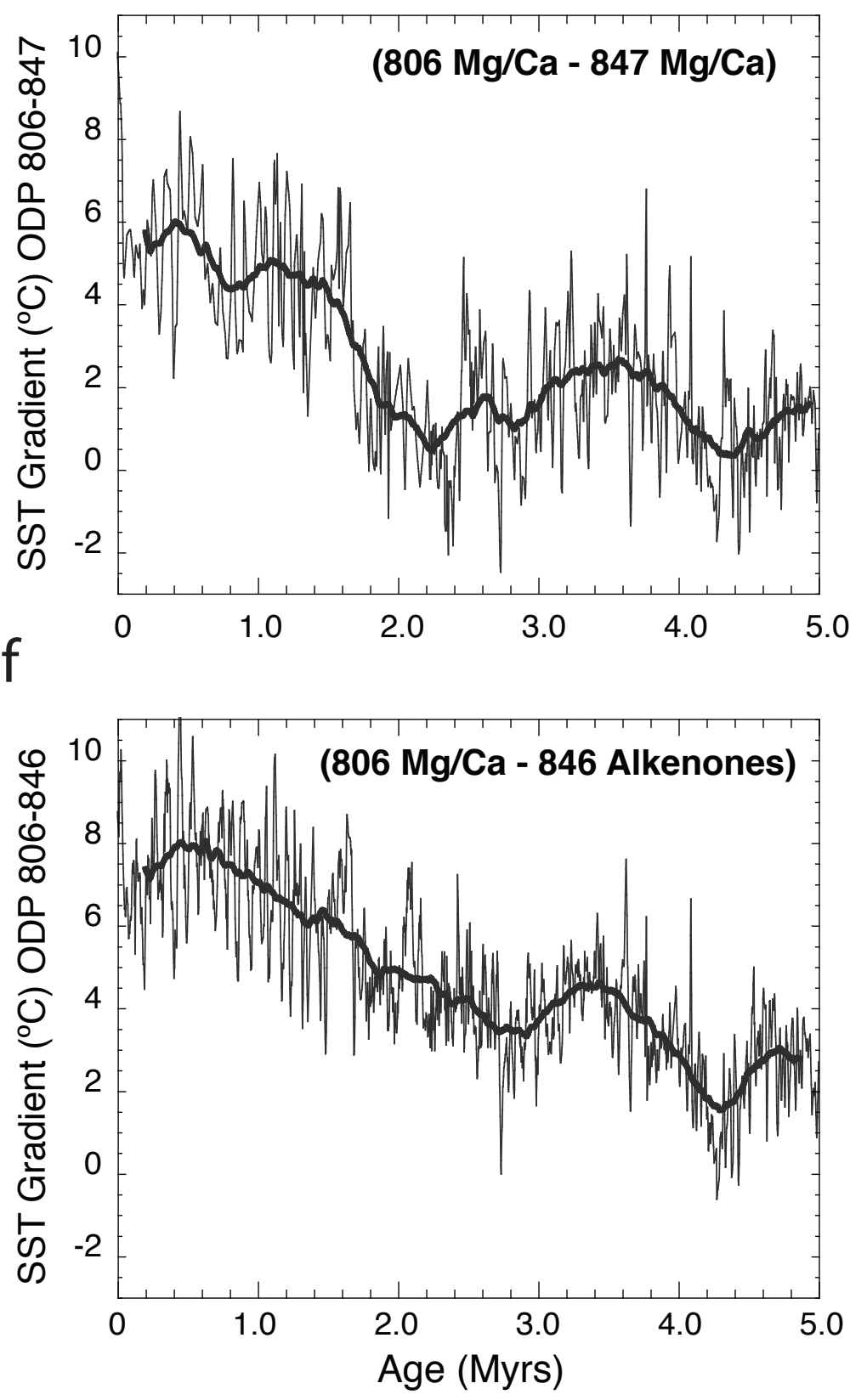

Figure 4 


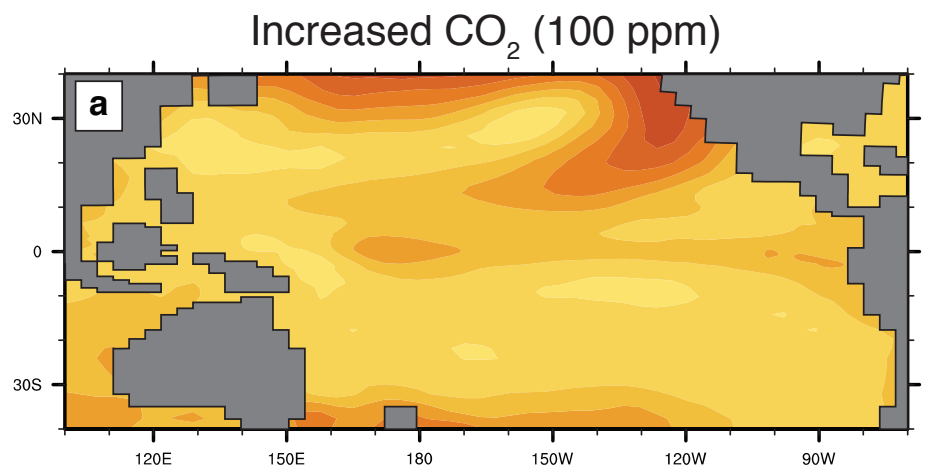

Broader Indonesian Throughflow

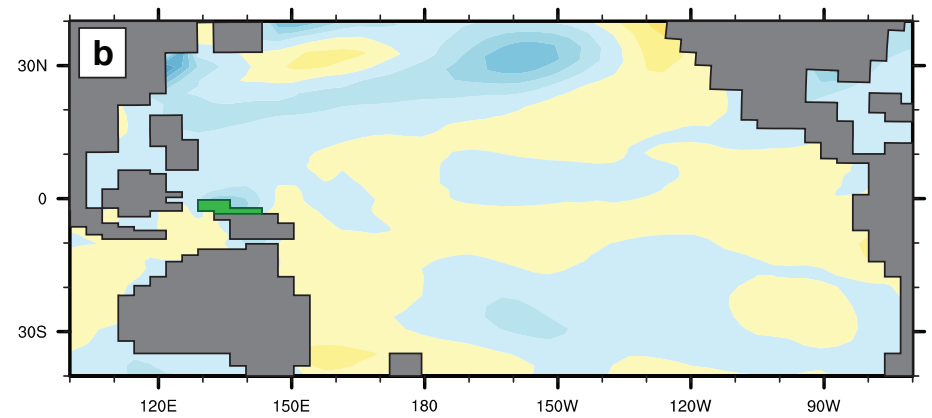

Shallow Central American Seaway (150 m)

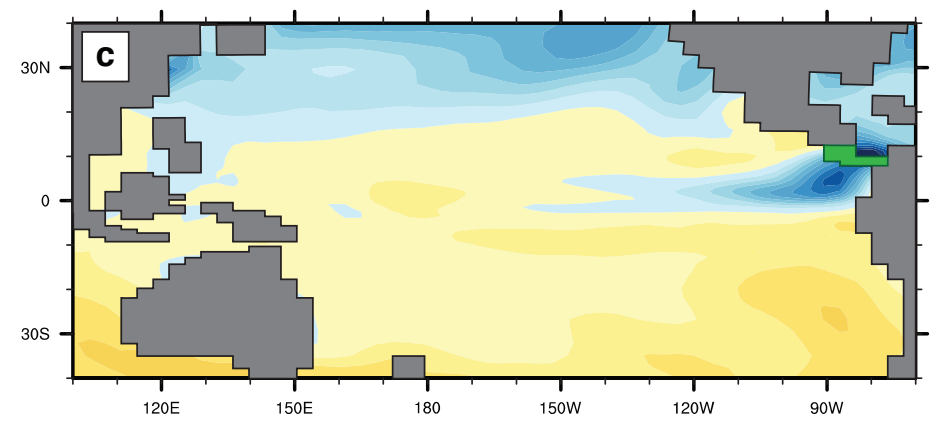

Enhanced Ocean Mixing

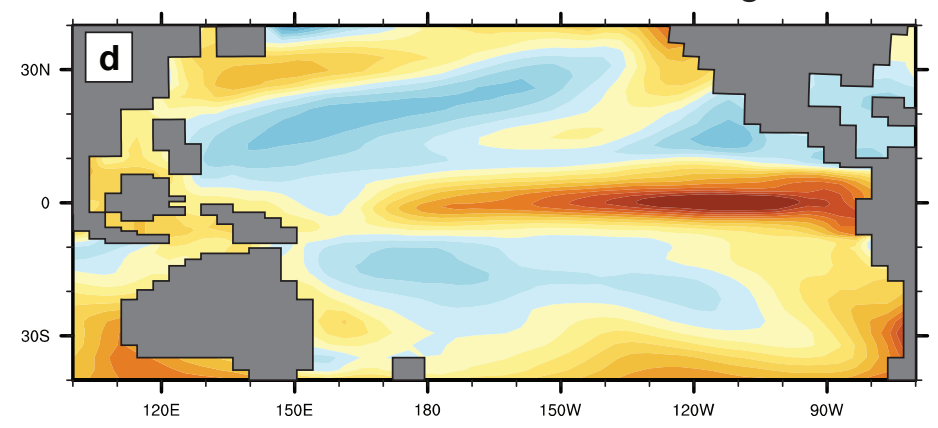

Reduced Cloud Albedo

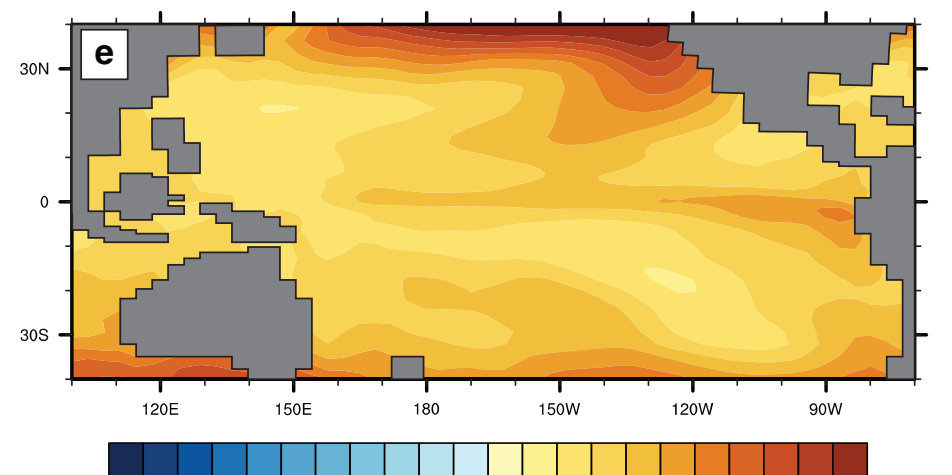

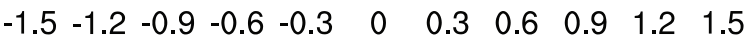

Figure 5
Increased $\mathrm{CO}_{2}(100 \mathrm{ppm})$

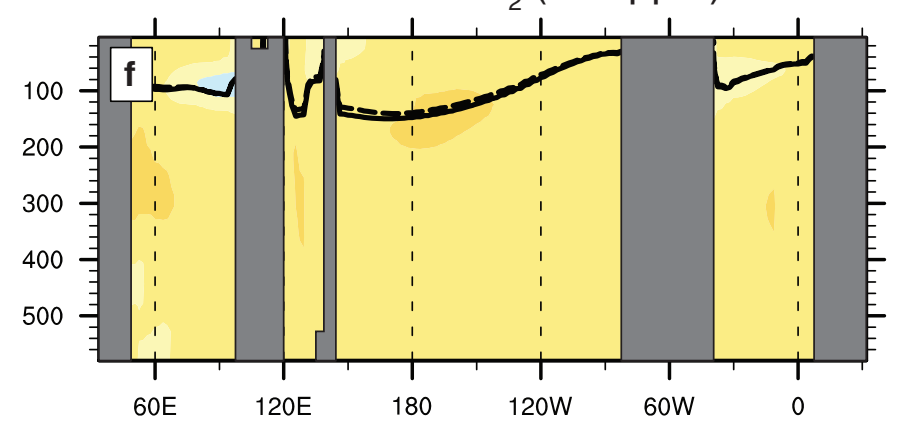

Broader Indonesian Throughflow

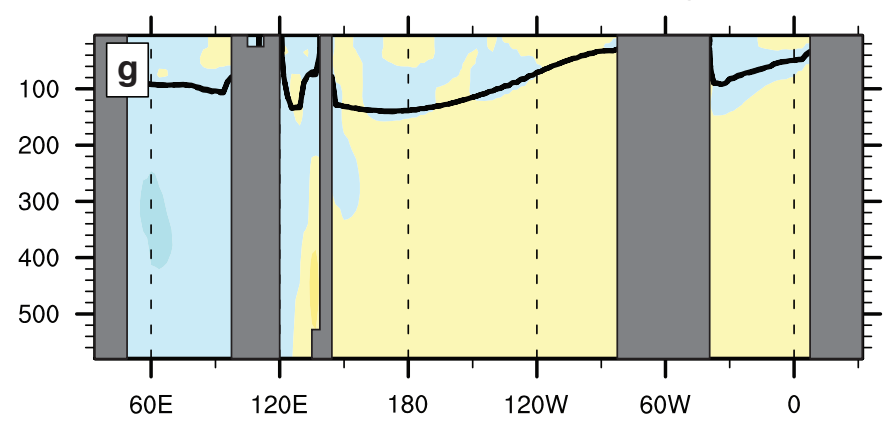

Shallow Central American Seaway (150 m)

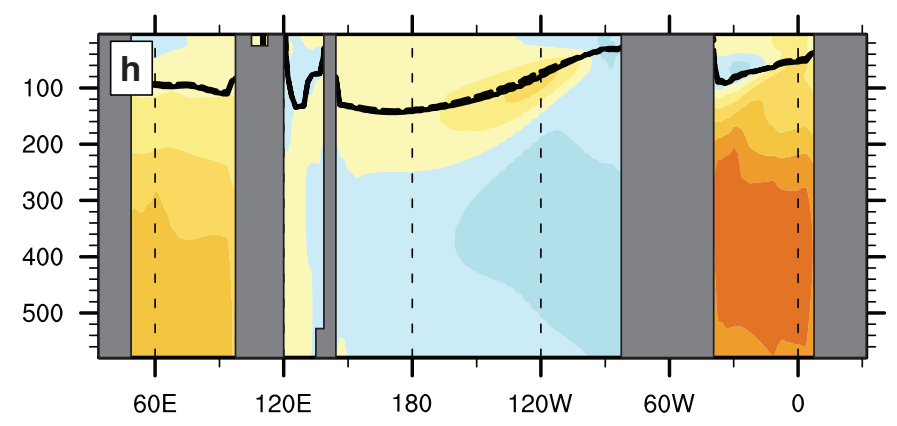

Enhanced Ocean Mixing

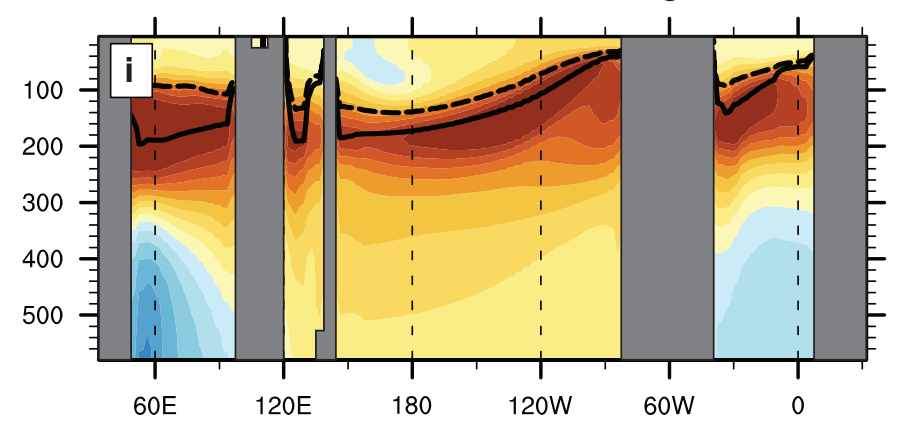

Reduced Cloud Albedo

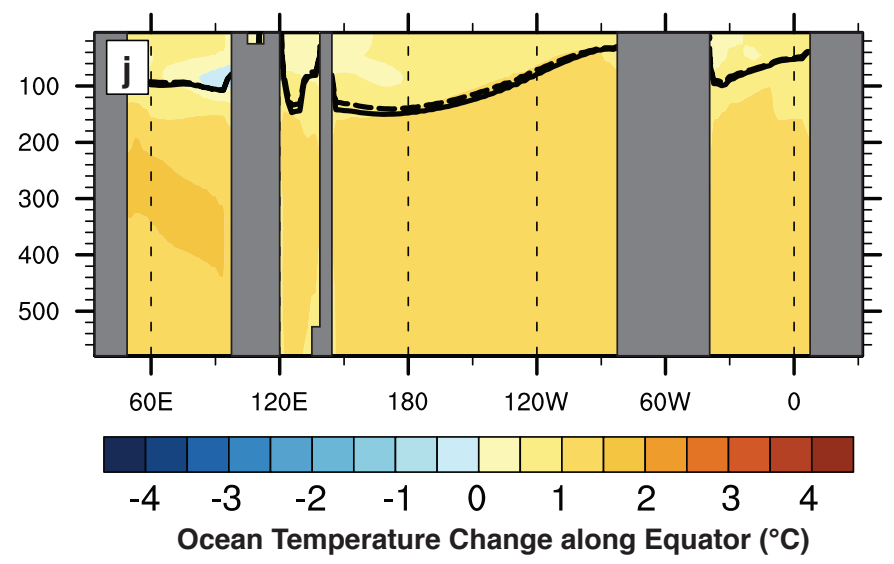



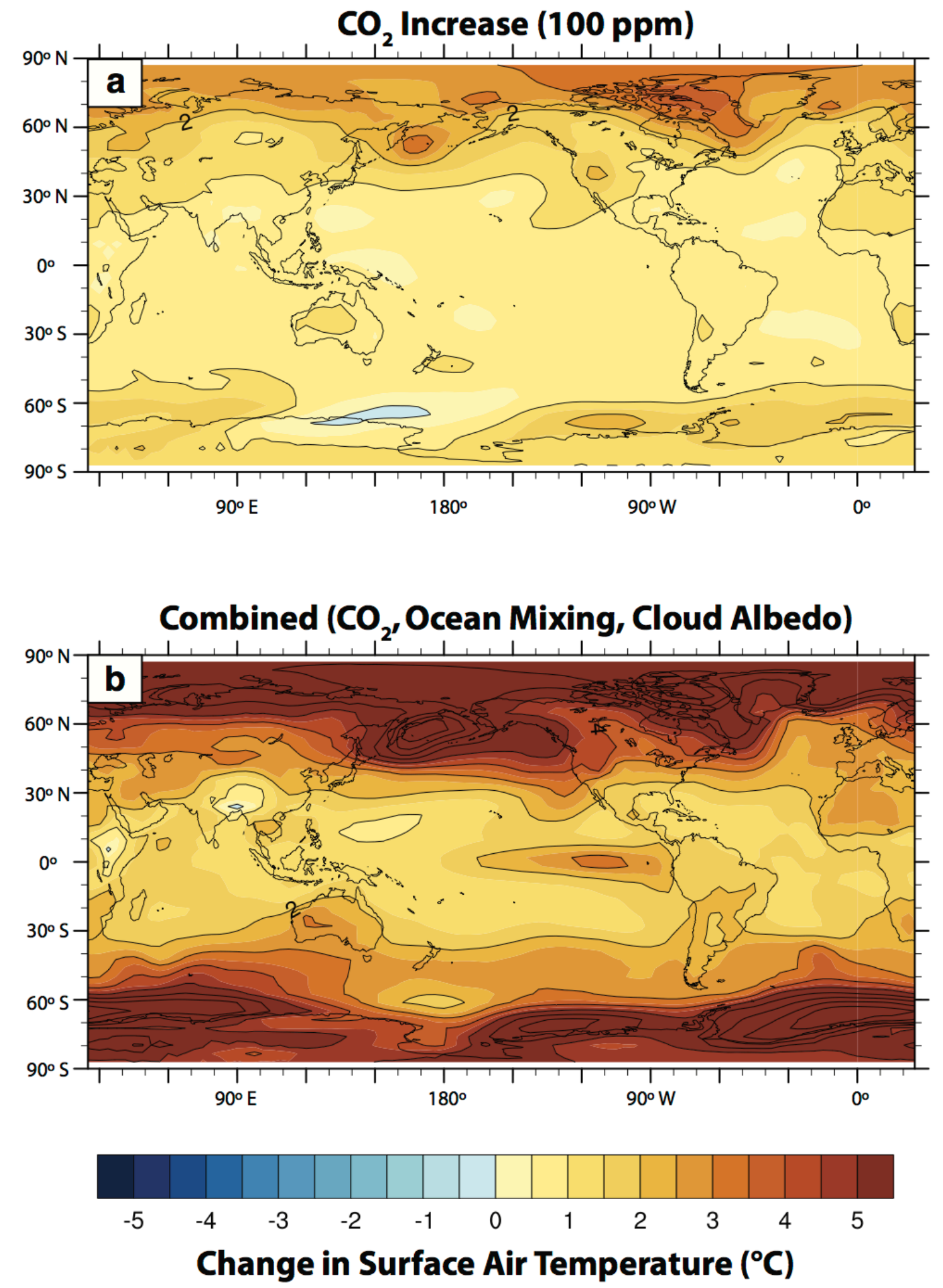

Figure 5 